\title{
Evaluation of aerosol number concentrations in NorESM with improved nucleation parameterization
}

\author{
R. Makkonen ${ }^{1, *}$, Ø. Seland ${ }^{2}$, A. Kirkevåg ${ }^{2}$, T. Iversen ${ }^{1,2}$, and J. E. Kristjánsson ${ }^{1}$ \\ ${ }^{1}$ Department of Geosciences, University of Oslo, P.O. Box 1047 Blindern, 0316 Oslo, Norway \\ ${ }^{2}$ Norwegian Meteorological Institute, P.O. Box 43 Blindern, 0313 Oslo, Norway \\ *now at: Department of Physics, University of Helsinki, P.O. Box 64, 00014 Helsinki, Finland
}

Correspondence to: R. Makkonen (risto.makkonen@helsinki.fi)

Received: 25 September 2013 - Published in Atmos. Chem. Phys. Discuss.: 11 October 2013

Revised: 12 March 2014 - Accepted: 19 March 2014 - Published: 26 May 2014

\begin{abstract}
The Norwegian Earth System Model (NorESM) is evaluated against atmospheric observations of aerosol number concentrations. The model is extended to include an explicit mechanism for new particle formation and secondary organic aerosol (SOA) formation from biogenic precursors. Three nucleation mechanisms are included in NorESM: binary sulfuric acid, activation type, and organic nucleation. Ten model experiments are conducted to study the sensitivity of the simulated aerosol number concentrations to nucleation, SOA formation, black carbon size distribution and model meteorology. Simulated vertical profiles are evaluated against 12 flight campaigns. Comparison of monthly averaged aerosol number concentrations against 60 measurement sites reveals that the model with explicit nucleation and SOA scheme performs well in terms of correlation coefficient, $R^{2}=0.41$ and a bias of $-6 \%$. NorESM generally overestimates the amplitude of the seasonal cycle, possibly due to underestimated sinks or exaggerated sensitivity to biogenic precursors.
\end{abstract}

\section{Introduction}

Atmospheric aerosol particles affect climate not only by scattering and absorbing radiation, but by acting as cloud condensation nuclei $(\mathrm{CCN})$ and affecting the dynamical and radiative properties of clouds. A recent multimodel effort in the AeroCom framework (Myhre et al., 2013) found anthropogenic direct radiative forcing estimates ranging from -0.58 to $-0.02 \mathrm{~W} \mathrm{~m}^{-2}$, i.e. all 16 models estimate a climate cooling effect from the direct aerosol effect (scattering and absorption of radiation). However, not all aerosols are cooling: the same study by Myhre et al. (2013) found a model median direct forcing of $+0.23 \mathrm{~W} \mathrm{~m}^{-2}$ for black carbon (BC) from fossil fuel and biofuel combustion, and a best estimate of total BC forcing (including clouds and cryosphere) of $+1.1 \mathrm{~W} \mathrm{~m}^{-2}$ was found by Bond et al. (2013). Due to potential high gains, the mitigation of climate warming by effective reduction in black carbon (BC) has been increasingly discussed in recent years (e.g. Anenberg et al., 2012).

Although anthropogenic aerosols probably contribute to a net climate cooling via aerosol direct effect, the human influence on Earth's radiative balance is likely to be even stronger via the aerosol indirect effect. The IPCC reported that the aerosol-induced modification of the cloud albedo causes a negative forcing between -2.2 to $-0.5 \mathrm{~W} \mathrm{~m}^{-2}$ (Forster et al., 2007), and the indirect effects beyond cloud albedo effect can be of similar magnitude (Lohmann and Feichter, 2005). Compared to the direct radiative effect, the aerosol indirect effect is more difficult to estimate by modelling. In addition to a realistic description of cloud formation, the aerosolcloud interactions are very sensitive to the aerosol size distribution, size-segregated composition information and aerosol mixing state.

Information on the aerosol size distribution and number concentration has been included in global aerosol models for more than a decade (Von Salzen et al., 2000; Ghan et al., 2001; Adams and Seinfeld, 2002). However, aerosol microdynamics are extremely difficult to model on the global scale. First, many aerosol dynamical processes, such as coagulation, are computationally demanding and need to be simplified for modelling purposes. Second, some relevant 
processes, such as atmospheric nucleation, remain poorly understood and constrained. Even the discretization of the aerosol population information is demanding: most global aerosol models use either modal (e.g. Stier et al., 2005; Mann et al., 2010) or sectional (e.g. Adams and Seinfeld, 2002; Spracklen et al., 2005) approaches, but the number of modes or bins is restricted by computational constraints. The degradation of aerosol size distribution information begins already at the point of emission, when models generally use simple conversions from aerosol mass to number emission. Recently however, direct aerosol number emissions have also been applied on the European scale (Fountoukis et al., 2012; Kulmala et al., 2011).

Development of global aerosol models has both improved simulated aerosol number concentrations and revealed crucial information on the relative importance of aerosol processes in the atmosphere. Aerosols form either by emission of primary particles or by formation of secondary aerosol material in the atmosphere. To affect particle number concentration, secondary aerosol formation must lead to the formation of a new particle via nucleation. Globally averaged, primary emissions dominate the atmospheric aerosol mass loading due to sea salt and dust emissions. With regard to particle number, however, atmospheric nucleation can explain a major fraction of concentrations in the boundary layer, and even $99 \%$ above $5 \mathrm{~km}$ (Merikanto et al., 2009). While anthropogenic emissions contribute only a small amount to the total aerosol mass, the addition to aerosol number concentration can be $35 \%$ (Makkonen et al., 2012b).

In this paper we evaluate the aerosol number concentrations simulated by the Norwegian Earth System Model (NorESM). The model is extended to include an explicit mechanism of nucleation and secondary organic aerosol (SOA) formation. Model evaluation is performed against 60 measurement stations, aerosol measurement campaigns, vertical observations from flight campaigns and a compilation of marine aerosol number concentrations. With the help of sensitivity simulations, we investigate the relative roles of different processes and emissions affecting the simulated number concentration. The results will help assessing the performance of the aerosol dynamics in NorESM. The comparison of the sensitivity simulations gives an indication of the relative importance of secondary aerosol formation and primary aerosol emission to aerosol number concentrations.

\section{Model description}

\subsection{NorESM1-M}

The first version of the Norwegian Earth System Model, NorESM1, is one of the Earth System Models participating in the Coupled Model Intercomparison Project Phase 5 (CMIP5). The median atmospheric resolution $\left(1.9^{\circ} \times 2.5^{\circ}\right)$ version of the model, NorESM1-M, is based on the CCSM4
(Gent et al., 2011; Vertenstein et al., 2010) developed at the National Center for Atmospheric Research (NCAR). NorESM differs from CCSM4 in several aspects. The ocean model POP2 is replaced with a Bergen-developed version of MICOM (Otterå et al., 2009), and the ocean biogeochemistry HAMburg Ocean Carbon Cycle model HAMOCC (MaierReimer, 1993; Maier-Reimer et al., 2005) is coupled to the ocean model. The atmospheric model CAM4 is replaced by CAM4-Oslo (Kirkevåg et al., 2013). As CCSM4, NorESM1$\mathrm{M}$ includes the Community Land Model (CLM, Oleson et al., 2010) and the Los Alamos Sea Ice Model (CICE). Interface between model components is handled via CPL7 coupler. This CMIP5 version of NorESM (Bentsen et al., 2013) has been evaluated in terms of climate response and future scenarios (Iversen et al., 2013). According to Bentsen et al. (2013), NorESM1-M underestimates cloudiness by 13$24 \%$ (ISCCP and CLOUDSAT, respectively) and continental near-surface temperatures by about $1.1 \mathrm{~K}$ globally averaged. The climate sensitivity of NorESM1-M is in the lower range of CMIP5 models (Iversen et al., 2013).

\subsection{CAM4-Oslo}

The aerosol model in CAM4-Oslo describes the transport and size-resolved aerosol physics and chemistry of 20 aerosol components. The aerosol module combines a life-cycle model, which describes the emissions, processing and transport of aerosol mass, and look-up tables calculated by an offline microphysics model. The look-up tables are used to calculate the physical and optical properties of the aerosol population. Aerosols are activated as cloud droplets following Abdul-Razzak and Ghan (2000). A more detailed description of CAM4-Oslo can be found in Kirkevåg et al. (2013).

Sea salt emissions produce particles in three different modes: Aitken (median diameter $\bar{d}=44 \mathrm{~nm}$ ), accumulation $(\bar{d}=260 \mathrm{~nm})$ and coarse $(\bar{d}=1480 \mathrm{~nm})$. Dust is emitted in accumulation $(\bar{d}=440 \mathrm{~nm})$ and coarse modes $(\bar{d}=1260 \mathrm{~nm})$. Sulfate can condense on all these five modes. $\mathrm{BC}$ is included in five modes of CAM4-Oslo. First, fossil fuel emissions produce two types of $\mathrm{BC}$ particles: nucleationmode size $(\bar{d}=23.6 \mathrm{~nm})$ and accumulation-mode size fractal agglomerates $(\bar{d}=200 \mathrm{~nm})$. The nucleation-mode BC can become coated with sulfate and moved to a larger, aged $\mathrm{BC}$ mode. The BC and organic carbon (OC) associated with biomass burning are emitted to an internally mixed mode. In addition to biomass burning emissions, this OC/BC mode is used also for OC emissions from fossil fuels and the production of SOA. The initial diameter of the OC/BC mode is $80 \mathrm{~nm}$.

Sulfuric acid produced in the gas phase can either condense on the pre-existing particle distribution or nucleate as new particles. Nucleation-mode particles (initial $\bar{d}=23.6 \mathrm{~nm}$ ) can grow to Aitken-mode size if not lost by coagulation. Details of the nucleation process are presented in Sect. 2.4.1. 


\subsection{Emissions}

The anthropogenic emissions for year 2000 are used in all simulations. The emissions are from the IPCC AR5 data set (Lamarque et al., 2010). Emissions of sea salt are modelled interactively as a function of $10 \mathrm{~m}$ wind speed and seasurface temperature according to Struthers et al. (2011), with some updates as described by Kirkevåg et al. (2013). The dimethyl sulfide (DMS) and dust emissions are prescribed daily values based on AeroCom inventory (Dentener et al., 2006). Volcanic $\mathrm{SO}_{2}$ emissions are modelled according to the AeroCom emission inventory (Dentener et al., 2006) and distributed evenly throughout the year.

The terrestrial biogenic volatile organic compound (BVOC) emissions of monoterpene and isoprene are taken into account. The BVOC emissions are prescribed monthly averages calculated with MEGAN2, amounting to $80 \mathrm{Tg}(\mathrm{C}) \mathrm{yr}^{-1}$ for monoterpene and $530 \mathrm{Tg}(\mathrm{C}) \mathrm{yr}^{-1}$ for isoprene. A VOC source over oceans is not included, although oceans are potentially a significant source of VOCs (Shaw et al., 2010). However, NorESM does include a primary organic aerosol source over oceans (Kirkevåg et al., 2013), which is scaled to $8 \mathrm{Tg} \mathrm{yr}^{-1}$ as estimated in Spracklen et al. (2011).

While the BVOC, wildfire, biomass burning, DMS, dust and sea salt emissions in NorESM have seasonal variation, the anthropogenic fossil fuel emissions are annual averages distributed evenly throughout the year. A diurnal emission cycle is only included in the interactive sea salt emission.

\subsection{Implemented modifications in NorESM}

We have developed NorESM1-M to include an explicit mechanism for nucleation, nuclei growth and SOA formation. The details of the modifications are described below.

\subsubsection{Nucleation}

The NorESM version in Kirkevåg et al. (2013) includes an implicit mechanism for new particle formation: after condensation, all excess sulfuric acid is assumed to form new particles. Sulfuric acid is not a traced variable. The nucleated particles are placed in the nucleation mode with an initial diameter of $23.6 \mathrm{~nm}$.

We have implemented the gaseous sulfuric acid as a prognostic variable, and included a mechanistic description of the nucleation process. Binary homogeneous sulfuric acidwater nucleation is implemented in NorESM according to the parameterization by Vehkamäki et al. (2002). This mechanism is applied throughout the atmosphere, and has been shown to produce a band of particles in the upper troposphere and lower stratosphere (UTLS) (e.g. Makkonen et al., 2009). However, binary homogeneous nucleation cannot explain the nucleation events observed in the boundary layer (Spracklen et al., 2006). For this reason, global aerosol models gener- ally apply either ternary sulfuric acid-ammonia-water nucleation (Pierce and Adams, 2009), ion-induced nucleation (Yu et al., 2008) or a semi-empirical nucleation parameterization (Makkonen et al., 2009) to the model. Ternary nucleation has been shown to perform well in some cases (Gaydos et al., 2005) but generally produces too high number concentrations in the troposphere (Lucas and Akimoto, 2006). Here, we have included activation-type nucleation (Kulmala et al., 2006; Sihto et al., 2006)

$J_{2}=A\left[\mathrm{H}_{2} \mathrm{SO}_{4}\right]$,

where the formation rate of $2 \mathrm{~nm}$ particles, $J_{2}$, is a linear function of the sulfuric acid concentration. The activation coefficient $A=1.7 \times 10^{-6} \mathrm{~s}^{-1}$ is taken from Paasonen et al. (2010). The activation-type nucleation is restricted to the boundary layer.

The nucleated particles are of $1-2 \mathrm{~nm}$ diameter. To save computational effort, we do not include the nucleated particles directly in the aerosol model. Instead, we use the parameterization by Lehtinen et al. (2007) to calculate the formation rate $J_{x}$ of particles at the diameter of the nucleation mode:

$J_{x}=J_{\text {nuc }} \exp \left(-\gamma \cdot d_{\text {nuc }} \frac{\operatorname{CoagS}\left(d_{\text {nuc }}\right)}{\mathrm{GR}}\right)$,

where $d_{x}$ is the nucleation-mode size, $J_{\text {nuc }}$ is the nucleation rate of $d_{\text {nuc }}$ sized particles, CoagS is the coagulation sink $\left(\mathrm{s}^{-1}\right)$ and GR is the particle growth rate. The factor $\gamma$ is a function of $d_{\text {nuc }}$ and $d_{x}$

$\gamma=\frac{1}{m+1}\left[\left(\frac{d_{x}}{d_{\text {nuc }}}\right)^{(m+1)}-1\right]$.

The exponent $m$ depends on the background aerosol distribution, and could be estimated from coagulation sinks of $d_{\text {nuc }}$ and $d_{x}$ sized particles (Lehtinen et al., 2007). Here we assume $m=-1.6$, which is in the typical range of atmospheric values (Lehtinen et al., 2007).

Coagulation sink CoagS $\left(d_{\text {nuc }}\right)$ for nuclei is calculated from NorESM aerosol modes. The above formula does not consider intramodal coagulation, which could be important if nucleation rates are extremely high (Anttila et al., 2010). In the case of activation-type nucleation (Eq. 1) we calculate $J_{x}$ from formation rate of $d_{\text {nuc }}=2 \mathrm{~nm}$ sized particles, i.e. $J_{\text {nuc }}=J_{2}$. By default, we convert the nucleation rates to formation rates of $24 \mathrm{~nm}$ particles $\left(J_{x}=J_{24 \mathrm{~nm}}\right)$ which are then implemented in the nucleation mode of NorESM. The nuclei growth rate GR is calculated from concentrations of sulfuric acid and organic vapours (see Sect. 2.4.3) according to Kerminen and Kulmala (2002).

The greater the difference in sizes $d_{\text {nuc }}$ and $d_{x}$, the larger are the values assigned for $\gamma$ causing the formation rate $J_{x}$ to be relatively more sensitive to CoagS and GR than to the nucleation rate itself. One sensitivity simulation is made to test the effect of nucleation-mode diameter $d_{x}$ on aerosol number concentration. 


\subsubsection{SOA formation}

In standard NorESM1-M (Kirkevåg et al., 2013), SOA is introduced with a prescribed monthly surface source and the SOA mass is included to the OM/BC mode with assumed initial diameter of $\bar{r}=80 \mathrm{~nm}$. The SOA formation in NorESM1-M is $37.5 \mathrm{Tg} \mathrm{yr}^{-1}$ based on an estimate by Hoyle et al. (2007). Seasonal and temporal variation follow the MEGAN2 algorithm. To estimate the particle growth due to organic vapours, we implement an improved SOA scheme in NorESM. A biogenic source for monoterpenes and isoprene is included as prescribed monthly emission fields, precalculated by MEGAN2 (Guenther et al., 2006). These SOA precursors are then oxidized in the gas phase by $\mathrm{O}_{3}, \mathrm{OH}$ and $\mathrm{NO}_{3}$. The formed SOA is assumed to be non-volatile, and no gas phase tracers are included for the oxidation products. Currently, only monoterpene is assumed to form SOA, with a $15 \%$ yield. It is further assumed that $50 \%$ of the monoterpene ozonolysis products are of low enough volatility that they can partition to the nucleated particles (below $23.6 \mathrm{~nm}$ diameter) and also participate in nucleation itself. This is in accordance with Yli-Juuti et al. (2011) who showed a clear connection with nuclei mode growth and monoterpene ozonolysis. The improved SOA model changes aerosol formation in two ways: by changing the size distribution of formed SOA and by allowing SOA formation outside the surface level of the model.

\subsubsection{Growth of nucleated particles}

Oxidation products of VOCs have been directly linked to the formation and growth of atmospheric particles (Ehn et al., 2014). In many locations, the nuclei growth due to organic vapours can clearly exceed the growth by sulfuric acid. For example in Hyytiälä, Finland, sulfuric acid can only explain less than $10 \%$ of the particle growth (Riipinen et al., 2011). Experiments in the CLOUD (Cosmics Leaving Outdoor Droplets) project at CERN (l'Organisation européenne pour la recherche nucléaire) have shown that in the presence of organic vapour, organic volume fraction can increase from 0.4 to 0.9 when the particles grow from 2 to $63 \mathrm{~nm}$ (Keskinen et al., 2013). We assume that organic vapours can grow new particles until they reach nucleation mode. We do not include a tracer for organic mass in the nucleation mode of NorESM: particles entering the aerosol module from nucleation process are assumed to consist of sulfate. However, the nucleation-mode organic mass is very low compared to the total organic aerosol mass.

With the above setup, the modelled growth rates (GRs) are close to observations. For June, NorESM growth rates at Hyytiälä vary from 1.6 to $4.2 \mathrm{~nm} \mathrm{~h}^{-1}$, while the medians of observed June GRs are 2, 4 and $8 \mathrm{~nm} \mathrm{~h}^{-1}$ for particle size ranges $1.5-3,3-7$ and $7-20 \mathrm{~nm}$, respectively (Yli-Juuti et al., 2011). In the US Rocky Mountains, NorESM simulates a similar range of GR, from 1.0 for $2.6 \mathrm{~nm} \mathrm{~h}^{-1}$ (June-July), which is slightly lower than the observed $4 \mathrm{~nm} \mathrm{~h}^{-1}$ (Boy et al., 2008). Overall, our approach seems to underpredict particle growth to some extent, possibly due to unaccounted vapours.

The fraction of formed SOA which does not partition to nucleated particles will form SOA the same way as in Kirkevåg et al. (2013): it is lumped together with OC from biomass burning, fossil fuel and marine organic emissions. An initial diameter of $80 \mathrm{~nm}$ is assumed for the formed SOA. As such, the SOA model in NorESM is improved to take into account its possible role in nucleation and nuclei growth, but the model cannot capture the real nature of SOA formation. While the implemented modifications are likely to improve the simulated effect of SOA formation on particle number, the total SOA production may still remain underestimated (Spracklen et al., 2011).

\section{Sensitivity experiments}

We use NorESM to simulate aerosol number concentrations in a number of sensitivity experiments. The experiments are listed in Table 1 and described in the following sections.

\subsection{Black carbon size distribution}

The size distribution and the mixing state of $\mathrm{BC}$ are strong sources of uncertainty for modelled particle concentrations (Reddington et al., 2011, 2013). Reddington et al. (2013) showed a clear underestimation of BC particle size as well as an overestimation of the number fraction of particles containing a $\mathrm{BC}$ core. They suggested that the uncertainties are due to erroneously modelled $\mathrm{BC}$ particle mixing state assumptions and too small emission size distribution for a global model scale. Unlike the model in Reddington et al. (2013), NorESM includes two externally mixed modes for fossil fuel $\mathrm{BC}$ emission: a nucleation mode of diameter $23.6 \mathrm{~nm}$ and a fractal agglomerate mode of diameter $200 \mathrm{~nm}$. A small fraction of $10 \%$ of the BC emission is assumed to be agglomerated particles. The median diameter of the $\mathrm{BC}$ nucleation mode is slightly smaller than the AeroCom recommendation for fossil fuel BC $(30 \mathrm{~nm})$. However, the AeroCom recommendation does not include a separate agglomeration mode. The assumed BC diameter is smaller than used by many global aerosol models: $60 \mathrm{~nm}$ in Stier et al. (2005) and Zhang et al. (2012), $100 \mathrm{~nm}$ in Pierce and Adams (2007).

We address the sensitivity of NorESM aerosol number concentrations to fossil fuel $\mathrm{BC}$ emission size by simulations with two emission diameters, $23.6 \mathrm{~nm}$ (default for original NorESM1-M) and $47.2 \mathrm{~nm}$. The difference of a factor of 2 in the emission diameter leads to a factor of 8 times smaller emitted number of $\mathrm{BC}$ particles, which can lead to a notable effect in heavily polluted regions. The difference in BC number concentration will also affect new particle formation: the lower (higher) coagulation sink with larger (smaller) BC 
Table 1. Simulated sensitivity experiments. The simulated climate is identical in all experiments except ActNuc_BC48_Online, where aerosol-climate interactions are switched on.

\begin{tabular}{lllcc}
\hline Short name & Nucleation & BSOA & BC FF diameter $^{\text {Additional information }}$ \\
\hline NorESM1-M & On* & On & $23.6 \mathrm{~nm}$ & As in Kirkevåg et al. (2013) \\
NoNuc_BC24 & Off & On & $23.6 \mathrm{~nm}$ & \\
NoNuc_BC48 & Off & On & $47.2 \mathrm{~nm}$ & \\
ActNuc_BC24 & Eq. (1) & On & $23.6 \mathrm{~nm}$ & \\
ActNuc_BC48 & Eq. (1) & On & $47.2 \mathrm{~nm}$ & \\
OrgNuc_BC24 & Eq. (4) & On & $23.6 \mathrm{~nm}$ & \\
ActNuc_BC24_NoSOA & Eq. (1) & Off & $23.6 \mathrm{~nm}$ & \\
ActNuc_BC48_NoSOA & Eq. (1) & Off & $47.2 \mathrm{~nm}$ & \\
ActNuc_BC48_Online & Eq. (1) & On & $47.2 \mathrm{~nm}$ & Aerosols affect model meteorology \\
ActNuc_BC48_Nuc10 & Eq. (1) & On & $47.2 \mathrm{~nm}$ & SO4 nucleation-mode diameter set to 10 nm \\
\hline
\end{tabular}

* Original NorESM1-M assumed that after condensation, all excess sulfuric acid nucleates as new particles.

particles will act to increase (decrease) the survival of nucleated particles. This is taken into account in the calculation of coagulation sink in Eq. (2).

It should be noted that the applied emission inventory does not include any intra-annual variation for the fossil fuel emissions. This lack of emission seasonality stems from the emission data set construction and might reduce the correlation between simulated and observed concentrations. Monthly variation of anthropogenic emissions has been included in certain emission data sets (e.g. ECLIPSE, http://eclipse.nilu. no), but are not yet widely used in global aerosol modelling.

\subsection{Nucleation}

Although many global models tend to use activation-type nucleation by sulfuric acid as the default option, the actual mechanism behind atmospheric nucleation is still unresolved. There are indications that organic vapours play a role already in the nucleation process (Metzger et al., 2010), and including an organic vapour into the nucleation parameterization might lead to a better correlation with observations (Paasonen et al., 2010). We test the sensitivity of simulated number concentrations to nucleation rate by an additional simulation with organic nucleation:

$J_{2}=A_{\mathrm{S} 1}\left[\mathrm{H}_{2} \mathrm{SO}_{4}\right]+A_{\mathrm{S} 2}[\mathrm{ORG}]$.

The activation coefficients are $6.1 \times 10^{-7}$ and $0.39 \times 10^{-7} \mathrm{~s}^{-1}$ for $A_{\mathrm{S} 1}$ and $A_{\mathrm{S} 2}$, respectively (Paasonen et al., 2010). We assume that the organic vapours participating in nucleation in Eq. (4) are the same as those involved in nuclei growth, i.e. a $50 \%$ fraction of monoterpene ozonolysis products. Using organic nucleation will change the spatial distribution of particle formation. Also the spatial correlation between particle formation and organics available for particle growth might lead to increased survival of nuclei (Makkonen et al., 2012a).

An additional simulation is performed with nucleation turned off. In this case, the sulfuric acid which would other- wise nucleate, can now condense on the pre-existing particle population, making particle aging more efficient. One additional simulation is performed with a smaller diameter (10 $\mathrm{nm}$ ) for the nucleation mode (ActNuc_BC48_Nuc10).

\subsection{Particle growth}

Globally, organic vapours account for a large portion of nuclei growth. With more vapour available for growth, more nucleated particles will survive to reach the detection limit of the $\mathrm{CN}$ counter or the nucleation mode of NorESM. We investigate the role of BVOCs on particle number by simulations without SOA formation. In NorESM, this will affect number concentrations in two ways: decreasing the growth rate in Eq. (2) and the formation of the "primary" OC particles.

\subsection{Simulation setup}

For all simulations, we use anthropogenic emissions for the year 2000. The sea-surface temperatures are prescribed (AMIP-style run). The model is integrated for 5 years after 1 year spin-up. Monthly averages are calculated as multi-year climatological means over 5 simulation years.

We create one experiment to test the sensitivity to modelled meteorology. In all other simulations, the meteorology is unaffected by the CAM4-Oslo aerosols - that is, the meteorology in the various experiments is identical. However, the simulated climate can be very different from that affecting observed number concentrations. Additionally, the observations at different stations cover different time periods. The experiment ActNuc_BC48_Online couples the radiation, clouds and model meteorology to the CAM4-Oslo aerosols, thereby rendering the meteorology different from other experiments. The changes in meteorology affect the transport and deposition of aerosols. There is no reason to assume that the meteorology in any of the included simulations would be closer to the real-world meteorological state 
during the aerosol observations, but this approach can provide some estimate of uncertainty.

\section{Aerosol observations}

\subsection{Observations at measurement sites}

We compare NorESM aerosol number concentration against observations from 60 surface sites: 51 in the Northern Hemisphere and 9 in the Southern Hemisphere. Where available, we use several years of observations to achieve a representative distribution of aerosol number concentration. As NorESM is not simulated using reanalysed meteorology and emissions of year 2000 are used in all simulations, year-toyear comparisons are not feasible. While some stations are representative for a large surrounding region, some stations are affected by a local aerosol or precursor source. Local effects (e.g. plumes from power plant) could be filtered out of measurement data to some extent. However, we have used all available data from each station. Although NorESM cannot reproduce the effects of local pollution, the simulations can provide meaningful information on the background aerosol at the site. The names, locations and altitudes of the stations are listed in Table 4. The aerosol observation data are collected from three data bases (EBAS, WDCA and NOAA) and separate publications, as indicated in Table 4.

The experimental setup varies from one location to another, and aerosol number concentrations are measured with either condensation particle counters (CPCs), differential or scanning mobility particle sizers (DMPS/SMPS) or diffusion aerosol spectroscopes (DASs). The lower diameter cutoff ranges from 3 to $15 \mathrm{~nm}$ in different stations. Even with $15 \mathrm{~nm}$ cutoff diameter the measured particle size range covers basically all aerosol modes in NorESM, as the smallest NorESM modes have a median diameter of $24 \mathrm{~nm}$ by default. If particle size distribution information has been available for a station, we have omitted the possible smallest size bins $(3-10 \mathrm{~nm})$ from the measured station data. The implemented cutoff diameters are listed in Table 4.

Even with the relatively high number of stations, the spatial coverage of aerosol number concentration observations is rather poor. Most of Europe and parts of North America are rather well represented, while e.g. most of South America and Africa lack long-term observations of aerosol number. To make up for the unavailability of long-term data sets, we use campaign data to fill some of the spatial gaps.

\subsection{Vertical observations}

To complement the limitations of spatially fixed site observations, we use airborne measurements to evaluate the vertical distribution of NorESM aerosol concentrations. The flight campaign data are extracted from a compilation by Clarke and Kapustin (2010), which includes flight campaigns along Asian coastlines (ACE-Asia, TRACEP), South Pacific (ACE-

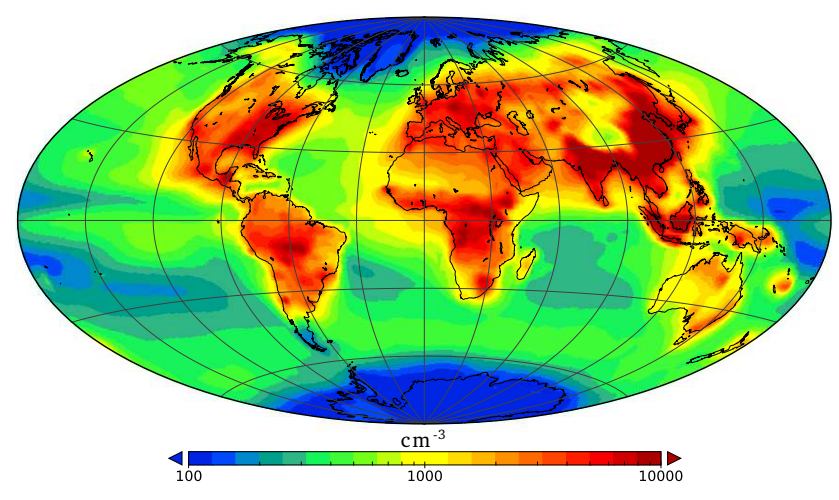

Figure 1. Annual mean surface-level aerosol number concentration $\left(\mathrm{cm}^{-3}\right)$ from ActNuc_BC24 simulation.

1, PEMT-A, PEMT-B), North Pacific (INTEX-B Hawaii, INTEX-B Alaska), Arctic (ARCTAS) and North America (IMPEX, INTEX-A, INTEX-B Houston). The observation cutoff diameter was $12-14 \mathrm{~nm}$ in ACE-Asia and PEMT-A, and $8-12 \mathrm{~nm}$ in other campaigns. The monthly average simulated fields are sampled over the regions indicated in Clarke and Kapustin (2010) and Fig. 4, hence the footprint of vertical profiles is not identical in simulations and measurements.

\subsection{Marine boundary layer}

To study aerosol number concentrations over oceans, we evaluate NorESM against the data compiled by Heintzenberg et al. (2000). The data set covers all major ocean regions, including data from both remote ocean and coastal sites. However, the data set does not include concentrations from the Northwestern Pacific, which is a major contributor to particle concentrations in NorESM. We mask out coastal regions (Supplement Fig. S1) in NorESM and focus on remote ocean regions.

\section{Results and discussion}

\subsection{General features of simulated number concentrations and responses to perturbations}

Figure 1 shows a map of annual-mean (5-year average) ground-level aerosol number concentration from a simulation with activation-type nucleation and small $\mathrm{BC}$ particles (ActNuc_BC24). Highest concentrations are found in Asia, peaking at $10000-50000 \mathrm{~cm}^{-3}$. Most land areas are covered by concentrations above $1000 \mathrm{~cm}^{-3}$, while pristine regions in Greenland and Antarctica reach concentrations as low as 100 and $10 \mathrm{~cm}^{-3}$, respectively. The model simulates a strong land-ocean contrast (Table 2) with number concentrations ranging between 890 and $3250 \mathrm{~cm}^{-3}$ over land and between 250 and $660 \mathrm{~cm}^{-3}$ over ocean in the NoNuc_BC48 and ActNuc_BC48_Nuc10 simulations, respectively. 
The four panels in Fig. 2 show the sensitivity of aerosol number concentration to nucleation, SOA formation, BC emission size and nucleation parameterization.

Nucleation is relatively least effective in the high windspeed band around $60^{\circ} \mathrm{S}$ (Fig. 2a), which is dominated by sea salt particles. Otherwise, nucleation increases aerosol number concentration over oceans by more than $20 \%$ in large areas. Some continental regions with high primary emissions, such as parts of Asia, show a sensitivity of $>5 \%$ to nucleation. In most cases, the increase in aerosol number due to nucleation is more than $20 \%$, or even $100-150 \%$ in North America and regional hotspots around volcanoes. The sensitivity of aerosol number concentration to nucleation in a certain area is the result of a combination of background particle sink and available vapours (sulfuric acid and organics). If the background sink is lowered, the relative importance of nucleation increases. This can be shown by comparing simulations ActNuc_BC24 and ActNuc_BC48 with their respective _NoNuc counterparts: with a lower sink, nucleation increases continental aerosol number concentration by $90 \%$ (ActNuc_BC48 vs. NoNuc_BC48), while a higher background sink shows a lower sensitivity of $50 \%$ to nucleation (ActNuc_BC24 vs. NoNuc_BC24). If SOA formation is turned off, the sensitivity is further suppressed to $40 \%$ (ActNuc_BC24_NoSOA vs. NoNuc_BC24_NoSOA), illustrating the importance of organic vapours for new particle formation and growth.

As shown in Table 2, turning on nucleation increases global average number concentration by $560 \mathrm{~cm}^{-3}$ with larger BC particles $(24 \mathrm{~nm})$, but only by $470 \mathrm{~cm}^{-3}$ with smaller BC particles due to increased coagulation sink. Decreasing the $\mathrm{SO}_{4}$ nucleation-mode diameter to $10 \mathrm{~nm}$ in the model almost doubles the simulated global number concentrations.

In many areas, the organics make a significant contribution to the increased survival of nucleated particles until they reach the nucleation-mode size in NorESM. This increases the sensitivity of aerosol number concentrations to SOA formation. Since we have not implemented SOA precursor emissions over oceans, the land-ocean contrast of SOA sensitivity is large (Fig. 2b): only the Arctic Ocean and westerly outflow from South America show concentration increases above $5 \%$ over ocean.

Decreasing the emission diameter of fossil fuel BC particles from 24 to $12 \mathrm{~nm}$ leads to an increase in number concentration of about $50-100 \%$ in central Europe and 100-150\% in polluted Asian regions (Fig. 2c). The effect of changes in $\mathrm{BC}$ size is generally confined to areas near continental emission sources, although some signal can be seen in the main shipping routes in the North Atlantic and Pacific Ocean.

Although the global aerosol number concentration is not sensitive to the choice of nucleation parameterization ( $5 \%$, Table 2), Fig. $2 \mathrm{~d}$ shows interesting spatial differences from ActNuc_BC24 and OrgNuc_BC24 simulations. In areas with strong biogenic VOC emissions, organic nucleation
Table 2. Global average surface-level number concentrations $\left(\mathrm{cm}^{-3}\right)$ from model experiments.

\begin{tabular}{lrrr}
\hline & Global & Land & Ocean \\
\hline NorESM1-M & 1534 & 2230 & 587 \\
NoNuc_BC24 & 973 & 1489 & 271 \\
NoNuc_BC48 & 618 & 890 & 248 \\
ActNuc_BC24 & 1444 & 2205 & 409 \\
ActNuc_BC48 & 1179 & 1754 & 398 \\
OrgNuc_BC24 & 1519 & 2340 & 403 \\
ActNuc_BC24_NoSoa & 1238 & 1858 & 396 \\
ActNuc_BC48_NoSOA & 960 & 1384 & 384 \\
ActNuc_BC48_Online & 1163 & 1738 & 381 \\
ActNuc_BC48_Nuc10 & 2155 & 3254 & 660 \\
\hline
\end{tabular}

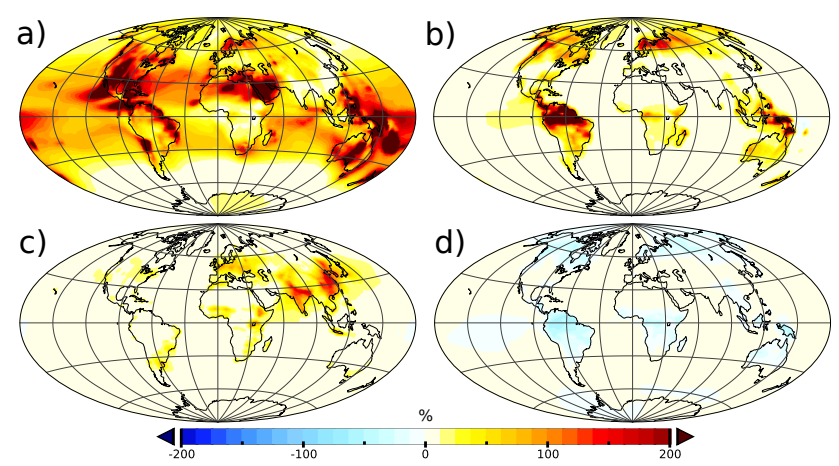

Figure 2. Surface-level aerosol number concentration difference fields (\%) from sensitivity simulations, due to (a) nucleation (ActNuc_BC24-NoNuc_BC24), (b) SOA formation (ActNuc_BC24-ActNuc_BC24_NoSOA), (c) BC emission size (ActNuc_BC24-ActNuc_BC48) and (d) nucleation parameterization (ActNuc_BC24-OrgNuc_BC24). Differences are calculated against ActNuc_BC24 simulation (Fig. 1).

(OrgNuc_BC24) can lead to 5-50\% higher concentrations, even $>50 \%$ over South America, compared to nucleation by sulfuric acid only (ActNuc_BC24). In areas dominated by anthropogenic emissions, activation-type nucleation (ActNuc_BC24) leads roughly to $5 \%$ higher concentrations than organic nucleation. Unfortunately, the spatial distribution of the effect of organic nucleation (Fig. 2d) corresponds to areas with poor coverage of observation stations included in this study, rendering it difficult to evaluate the role of organics on nucleation rate.

\subsection{Comparison to site observations}

Figure 3 shows the locations of the 60 sites used in the analysis. We investigate the performance of NorESM with respect to number concentration bias, defined as the difference between simulated and observed monthly average aerosol number concentration. We also calculate the correlation coefficients $R^{2}$ between the simulated and observed monthly mean concentrations to evaluate the simulated intra-annual 
variation of concentrations. The colour code of each station in Fig. 3 indicates the number concentration bias in simulation ActNuc_BC48 (blue: bias $<-20 \%$, red: bias $>+20 \%$ ). The contours in the background show simulated aerosol number concentrations from the ActNuc_BC48 experiment.

The stations are divided into six groups. First, we separate stations in the Arctic (Pallas, Värriö, Zeppelin and Point Barrow) and Antarctic (Dome C, South Pole, Troll and Neumayer). Next, we group stations located at high altitude (1000 $\mathrm{m}$ a.s.l.). However, some high-altitude stations belong to other groups based on their location or representativeness. Finally, we group remaining stations as marine, remote or rural. We use the classifications in Spracklen et al. (2010) and Henne et al. (2010) as guidance. While some stations are representative of a rather homogeneous region, other stations might exhibit diverse concentrations depending on e.g. wind direction.

\subsubsection{Arctic sites}

The comparison against Arctic sites is shown in Fig. 5. The simulations capture the seasonal variation in the Arctic with correlation coefficients ranging from $R^{2}=0.25$ without nucleation to $R^{2}=0.51$ with nucleation included. The Arctic sites Barrow and Zeppelin show very similar observed number concentration patterns with annual maximum (minimum) in July (October). In the Arctic, larger BC particles improve correlation with observations as compared to smaller BC size. Although Pallas and Värriö are high-latitude sites, they are heavily influenced by terrestrial biogenic emissions: when turning SOA production off in the model, the number concentrations decrease to the same level as in simulations without nucleation. The model simulations including nucleation and SOA formation overestimate the summer number concentrations in Pallas and Värriö, perhaps indicating too high sensitivity of new particle formation to organic vapours. On the other hand, simulations without nucleation or SOA formation underestimate the concentrations and magnitude of the seasonal cycle. At Point Barrow, the model simulates two distinct concentration peaks in AprilMay and July-August, while only the latter is found in the observations. The concentrations at Zeppelin are well reproduced, although winter concentrations are somewhat overestimated. The aerosol concentrations in the Arctic are sensitive to transport, and the simulation ActNuc_BC48_Online with different meteorology yields the highest correlation coefficient of $R^{2}=0.62$ and a bias of $+22 \%$, mostly due to differences at Point Barrow and Zeppelin stations.

\subsubsection{Marine sites}

NorESM has difficulties in simulating the number concentrations in marine areas (Fig. 6), where $R^{2}$ varies between 0.09 and 0.17 . NorESM includes a natural primary organic aerosol marine source (Kirkevåg et al., 2013), which is miss- ing in many global aerosol models. However, marine VOC emissions are neglected. In the NorESM version used in this study, the DMS emissions are prescribed daily fields for each grid box, hence they are not affected by model meteorology.

The number concentrations at Samoa, Sable Island and Cape Point are rather well simulated, if nucleation is included in the model. In marine sites, switching on nucleation turns the negative bias of -53 to $-31 \%$ (no nucleation) to a positive bias of 25-39\% (nucleation on). With the exception of Sable Island, the seasonal cycle is not improved by including either nucleation or SOA formation in the simulation. During the period January-May, nucleation is needed to explain concentrations in Cape San Juan; however nucleation overestimates concentrations during the rest of the year.

The model fails to simulate the seasonal concentration variation at Mace Head in the Northern Hemisphere and at Cape Grim in the Southern Hemisphere: at both locations, NorESM clearly overestimates the concentrations during summer and underestimates during winter. However, the observations at Mace Head and Cape Grim are highly variable, with even a factor of 3-4 between observed monthly mean and median concentrations. The coastal areas at Mace Head are a source of iodine compounds, which have been suggested as precursors for nucleation (O'Dowd and Hoffmann, 2005). These iodine nucleation events are not included in the model, which can account for a large fraction of the discrepancy between NorESM and observations. For Cape Grim, the simulations without nucleation correlate well with the observed monthly median values, but all model experiments fail to reproduce the mean concentrations. As in Spracklen et al. (2010), the model has difficulties in simulating the high mean concentrations observed at Cape Grim during winter months: in Spracklen et al. (2010), the model results are generally outside one standard deviation of the observations during the period May-September, although it seems that increasing the primary sulfate emissions slightly improves the simulated winter concentrations. The winter concentrations in NorESM are fairly insensitive to the simulated experiments. However, the observed variability of aerosol concentration at Cape Grim is considerable, and simulations without nucleation can capture the median concentrations throughout the year. The model also has trouble reproducing the relatively constant concentrations at Trinidad Head, where the overestimation of intra-annual variation is largely due to SOA: the _NoSOA experiments are almost identical to simulations without nucleation.

\subsubsection{Antarctic sites}

The Antarctic aerosol loading is affected by natural emissions of sea salt and DMS as well as long-range transport of dust and anthropogenic pollution (Kyrö et al., 2013). Local and regional new particle formation can also increase number concentrations in the Antarctic (Kyrö et al., 2013). The simulated Antarctic number concentrations are dominated by 
Table 3. Mean bias (\%) and correlation coefficient $R^{2}$ calculated over all stations and six regions.

\begin{tabular}{|c|c|c|c|c|c|c|c|c|c|c|c|c|c|c|}
\hline & \multicolumn{2}{|l|}{ All } & \multicolumn{2}{|c|}{ Arctic } & \multicolumn{2}{|c|}{ Marine } & \multicolumn{2}{|c|}{ Antarctic } & \multicolumn{2}{|c|}{ High altitude } & \multicolumn{2}{|c|}{ Remote } & \multicolumn{2}{|l|}{ Rural } \\
\hline & BIAS (\%) & $R^{2}$ & BIAS (\%) & $R^{2}$ & BIAS (\%) & $R^{2}$ & BIAS (\%) & $R^{2}$ & BIAS (\%) & $R^{2}$ & BIAS (\%) & $R^{2}$ & BIAS (\%) & $R^{2}$ \\
\hline NorESM1-M & 33 & 0.38 & 39 & 0.43 & 47 & 0.17 & 16 & 0.88 & 88 & 0.49 & -8 & 0.36 & 20 & 0.27 \\
\hline NoNuc_BC24 & -27 & 0.30 & -24 & 0.25 & -31 & 0.09 & -47 & 0.82 & -45 & 0.40 & -34 & 0.32 & -6 & 0.18 \\
\hline NoNuc_BC48 & -64 & 0.35 & -37 & 0.31 & -53 & 0.15 & -47 & 0.81 & -69 & 0.39 & -66 & 0.35 & -69 & 0.31 \\
\hline ActNuc_BC24 & 20 & 0.40 & 38 & 0.48 & 39 & 0.13 & -39 & 0.83 & 22 & 0.50 & 11 & 0.38 & 27 & 0.34 \\
\hline ActNuc_BC48 & -5 & 0.41 & 31 & 0.51 & 25 & 0.12 & -39 & 0.83 & 9 & 0.51 & -11 & 0.38 & -18 & 0.38 \\
\hline OrgNuc_BC24 & 20 & 0.39 & 54 & 0.43 & 41 & 0.13 & -39 & 0.83 & 20 & 0.49 & 12 & 0.36 & 25 & 0.34 \\
\hline ActNuc_BC24_NoSOA & 2 & 0.38 & -15 & 0.30 & 11 & 0.15 & -40 & 0.83 & 10 & 0.47 & -17 & 0.48 & 17 & 0.29 \\
\hline ActNuc_BC48_NoSOA & -25 & 0.42 & -24 & 0.41 & -5 & 0.15 & -41 & 0.83 & -3 & 0.48 & -41 & 0.53 & -31 & 0.38 \\
\hline ActNuc_BC48_Online & -8 & 0.43 & 22 & 0.62 & 23 & 0.15 & -36 & 0.76 & 4 & 0.51 & -11 & 0.40 & -20 & 0.39 \\
\hline ActNuc_BC48_Nuc10 & 81 & 0.38 & 349 & 0.47 & 160 & 0.10 & 17 & 0.53 & 94 & 0.45 & 48 & 0.38 & 31 & 0.37 \\
\hline
\end{tabular}

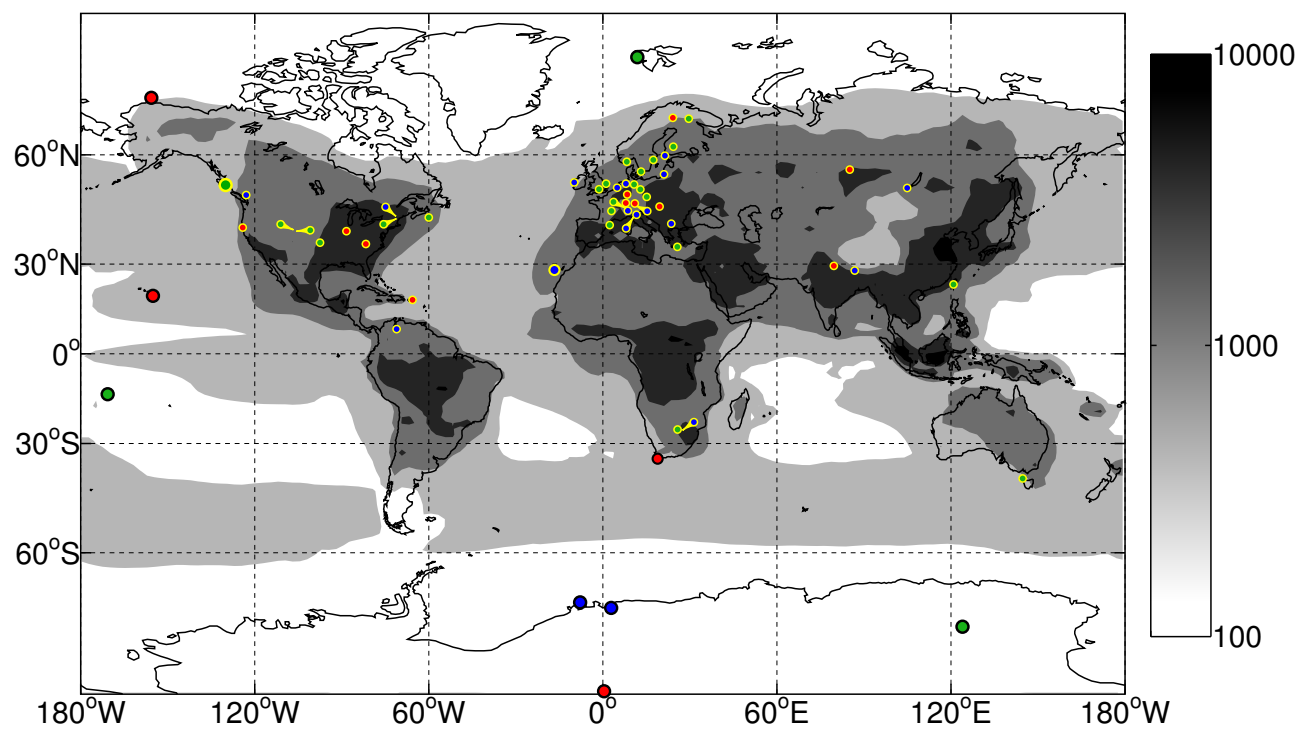

Figure 3. Locations of the sites used in this study coloured based on median number bias calculated from ActNuc_BC48. Red (blue) indicates a positive (negative) number bias higher than $20 \%$, while green shows stations with low bias $(<20 \%)$. The background contour shows number concentrations $\left(\mathrm{cm}^{-3}\right)$ from ActNuc_BC48 simulation. Size and outline colour of selected markers is adjusted for readability.

organic aerosol originating both from the Southern Ocean and continental sources, with some contribution from nucleation occurring at higher altitudes and transported to ground level. The simulated number concentrations in the Antarctic (Fig. 7) are rather insensitive to the performed model parameter perturbations, although the simulations with original NorESM1-M setup and experiment ActNuc_BC48_Nuc10 are somewhat separated due to strong nucleation in summer. All simulations show very high correlation with observations, with $R^{2}$ ranging from 0.76 to 0.88 (excluding ActNuc_BC48_Nuc10). Except for the South Pole site, the summer concentrations are generally underestimated. The extremely low observed winter concentrations of few tens to $100 \mathrm{~cm}^{-3}$ are well reproduced by NorESM.

\subsubsection{High altitude sites}

From the six categories in this study, the model performance for high-altitude sites (Fig. 8) is second-best in terms of monthly correlations against observations. The correlation coefficients averaged over all 14 sites range from 0.39 to 0.51 . While simulations without nucleation clearly underestimate concentrations, including nucleation improves model bias and increases correlation coefficient $R^{2}$ from 0.39-0.40 to $0.50-0.51$ (ActNuc_BC24 and ActNuc_BC48).

The model strongly exaggerates the intra-annual variation in Storm Peak Laboratory site, while the model can only explain about $10 \%$ of the wintertime concentrations. The Storm Peak measurement station is located very close to the Niwot Ridge station. Although the measurements at Niwot Ridge station were heavily influenced by local pollution from lower elevations, the simulations with nucleation (including NorESM1-M) reproduce the observed concentrations very well except for an overestimation during late summer. In many high-altitude sites the annual average concentrations are well reproduced, but the rise in number concentrations in early spring is usually underestimated (Jungfraujoch, Puy de Dôme, Zugspitze, Moussala, Mount Washington, Monte 


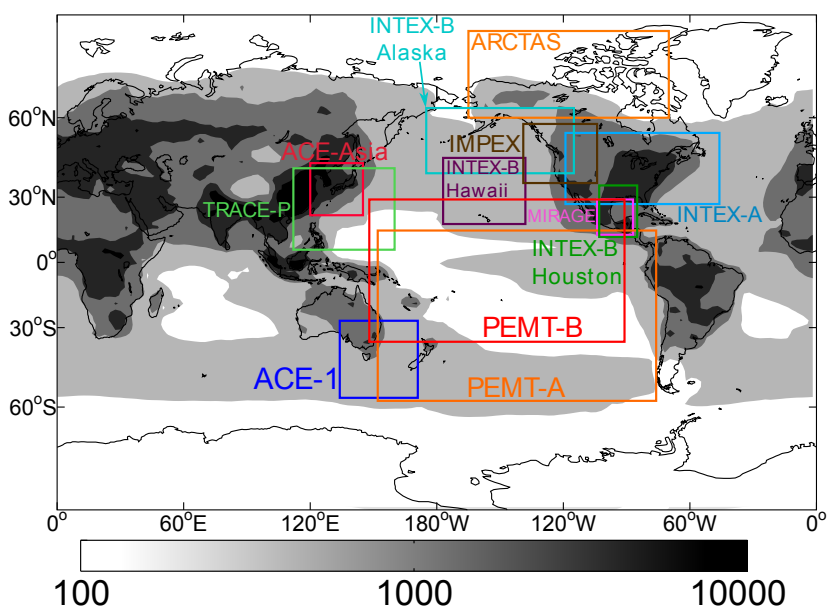

Figure 4. Locations of flight observation campaigns used in this study. The regions and flight observation data are from Clarke and Kapustin (2010). Background colour corresponds to aerosol number concentration $\left(\mathrm{cm}^{-3}\right)$ in simulation ActNuc_BC48.

Cimone). The only South American station in this evaluation is located at Pico Espejo, where the seasonality is extremely well reproduced $\left(R^{2}=0.47\right.$ for ActNuc_BC48_Nuc10), but the concentrations are generally slightly underestimated.

There is a strong contrast between model and observations at Mauna Loa: simulations indicate very high concentrations, mainly from nucleation (even $>90 \%$ ), whereas the observations show very little intra-annual variation and low concentrations. The $\mathrm{SO}_{2}$ emissions from Mauna Loa volcano have been reported declining, falling under detection limits by the year 2000. However, the volcanic emissions in NorESM, based on the AeroCom emission inventory, show high $\mathrm{SO}_{2}$ emission from the Kilauea volcano. Also, Mauna Loa stations is located at near $4000 \mathrm{~m}$ altitude, and model results from NorESM show strong transport from the western United States towards Mauna Loa during the summer (see comparison to INTEX-B Hawaii in Sect. 5.4).

\subsubsection{Remote sites}

At all remote stations except Listvyanka and Preila, the observed winter concentrations are well captured by the model (Fig. 9). However, the summer concentrations are generally overestimated (underestimated) by simulations with (without) nucleation. Since the seasonal cycle is generally overestimated in simulations with nucleation, turning off SOA formation actually improves the correlation coefficient (from $R^{2}=0.38$ to $R^{2}=0.48-0.53$ ). Still, simulations without SOA formation underestimate overall concentrations with a bias of -17 to $-41 \%$. The local concentration minimum, observed during July-August at Birkenes, Aspvreten, Hyytiälä and Vavihill, is not reproduced in the model simulations. The neighbouring stations Listvyanka and Tomsk seem similar in model results, while the simulated wildfire event in May is observed only in Tomsk.

\subsubsection{Rural sites}

With the high anthropogenic emissions at the rural sites, the model performance is highly sensitive to the selected model parameters (Figs. 10 and 11). The $R^{2}$ ranges from 0.21 with NoNuc_BC24 to 0.38 with ActNuc_BC48 and the bias ranges from a clear underestimation of $-69 \%$ with NoNuc_BC48 to $+31 \%$ with ActNuc_BC48_Nuc10. Although improving model bias, decreasing the $\mathrm{BC}$ emission size from 24 to $12 \mathrm{~nm}$ decreases the correlation coefficient from 0.38 to 0.34 and from 0.31 to 0.18 with and without nucleation, respectively. The original NorESM1-M has a bias of $+20 \%$, and including a mechanistic model for new particle formation can significantly improve the modelled seasonal cycle. Also, disabling SOA formation in the model degrades the simulated seasonal cycle.

NorESM can clearly not reproduce the high concentrations in the Po Valley or Ispra during wintertime, possibly due to omitted seasonality of anthropogenic emissions, overestimated scavenging or difficulties in simulating the boundary layer structure and topography with the coarse spatial resolution of NorESM. Although NorESM can capture the transport of pollutants from Northern Africa to Izaña, the local sources (vehicles, ships) dominate the observed number concentrations at the urban site (Gonzàlez et al., 2011). The concentrations at the Indian Himalayan station are well simulated without nucleation (NoNuc_BC48: $R^{2}=0.62$ ). Turning on nucleation (ActNuc_BC48) does not improve the correlation between measurements, but leads to a slight overestimation. The location is very much affected by local emissions in the simulations: decreasing $\mathrm{BC}$ emission size to $12 \mathrm{~nm}$ increases the simulated number concentrations by as much as a factor of 4 .

\subsubsection{Global-scale analysis against station observations}

Mean (median) correlation coefficients (Table 3) of monthly averages calculated over all stations range from $0.30(0.23)$ in NoNuc_BC24 to $0.42(0.50)$ in ActNuc_BC48_NoSOA. The online meteorology simulation ActNuc_BC48_Online (median $\left.R^{2}=0.46\right)$ performs somewhat better than the offline version ActNuc_BC48 (median $R^{2}=0.43$ ), which could indicate that the meteorology (transport, deposition) in the online simulations is on average closer to the actual meteorology during observations. Averaged over all stations, larger fossil fuel BC particles (BC48) result in better correlation than the smaller $12 \mathrm{~nm}$ particles. Without nucleation, the mean (median) correlation is increased from $0.30(0.23)$ to $0.35(0.31)$ when doubling of the $\mathrm{BC}$ emission size (NoNuc_BC24 vs. NoNuc_BC48). With nucleation turned on in the model, the respective mean (median) correlation coefficient increases from $0.40(0.39)$ to $0.41(0.43)$ due 

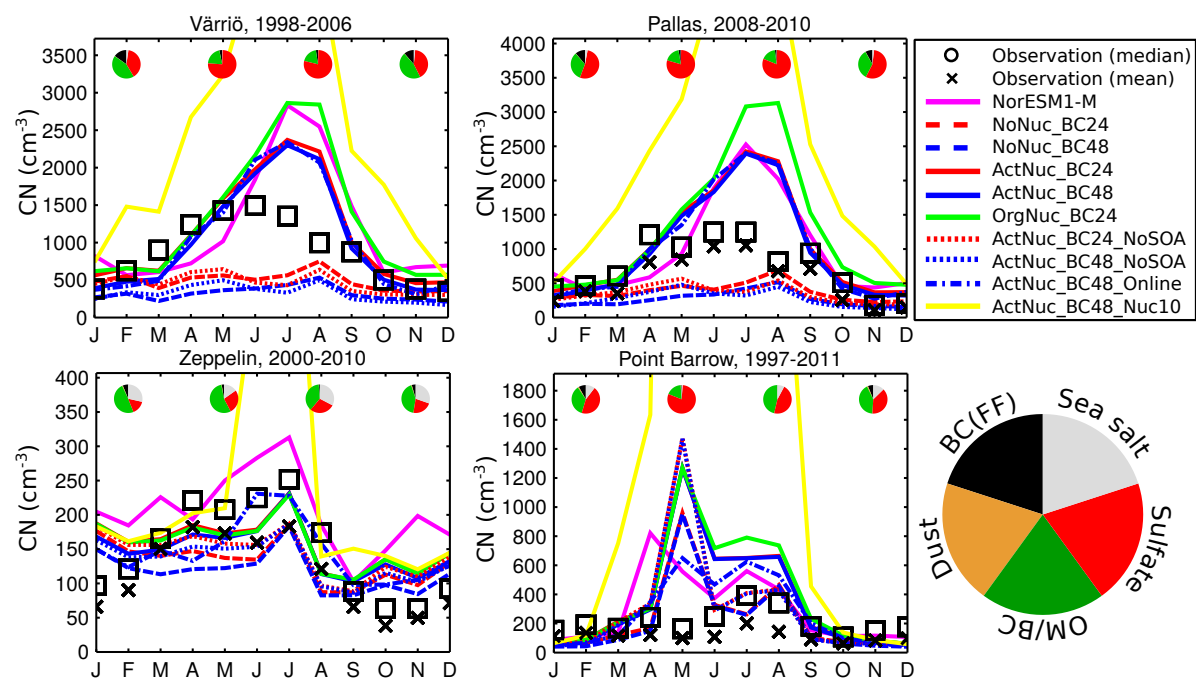

Figure 5. Comparison against Arctic site observations. The year range used for observation averaging is indicated at the top of each panel. The vertical axis is not scaled to include simulation ActNuc_BC48_Nuc10. The pie charts indicate the relative contribution of aerosol components to number concentration in NorESM simulations (ActNuc_BC48) in February, May, August and November. Included aerosol components are sea salt, sulfate, mixed OM/BC mode, dust and fossil fuel BC. For a detailed description of the NorESM aerosol model, see Kirkevåg et al. (2013).

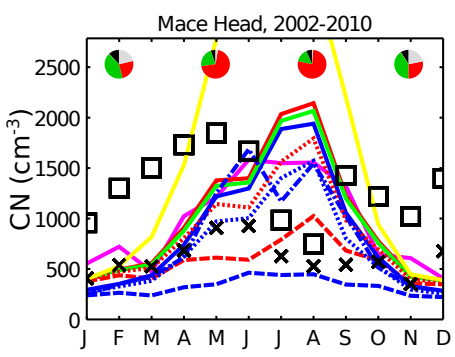

Cape San J uan, 2005-2011
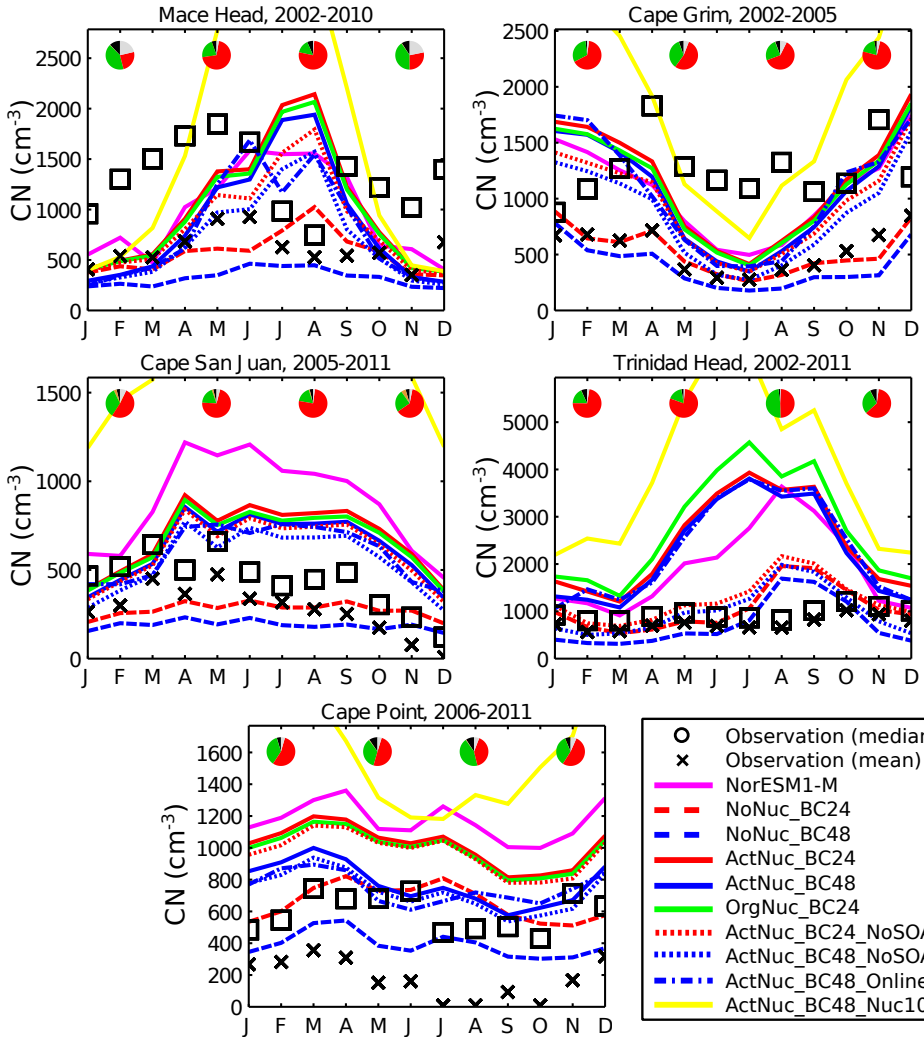

Trinidad Head, 2002-2011
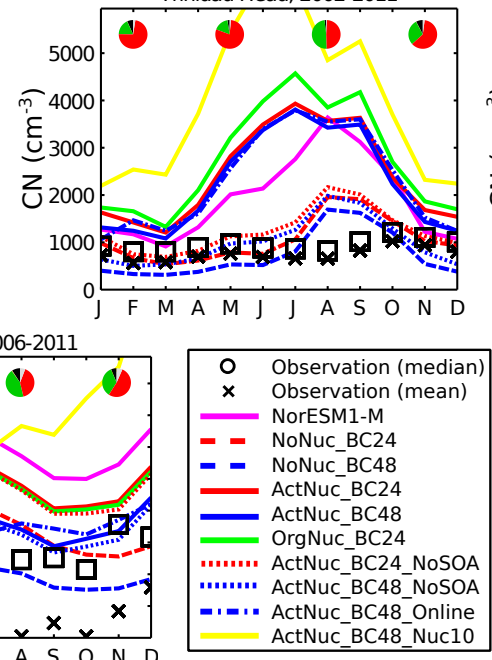

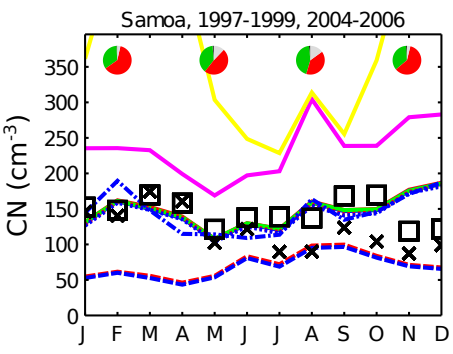

Sable Island, 1996-1999
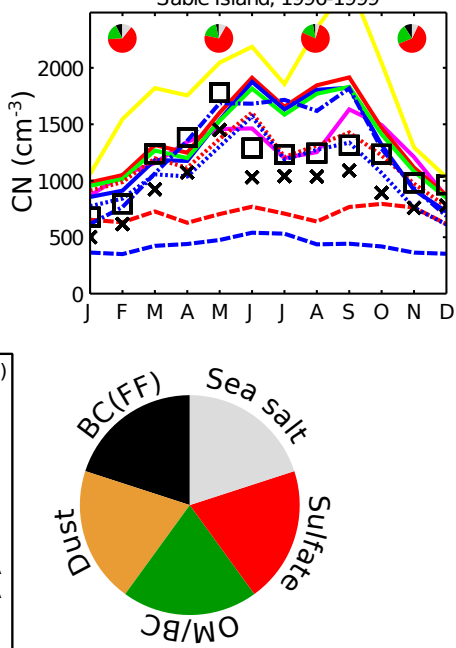

Figure 6. As Fig. 5, but for marine sites. 

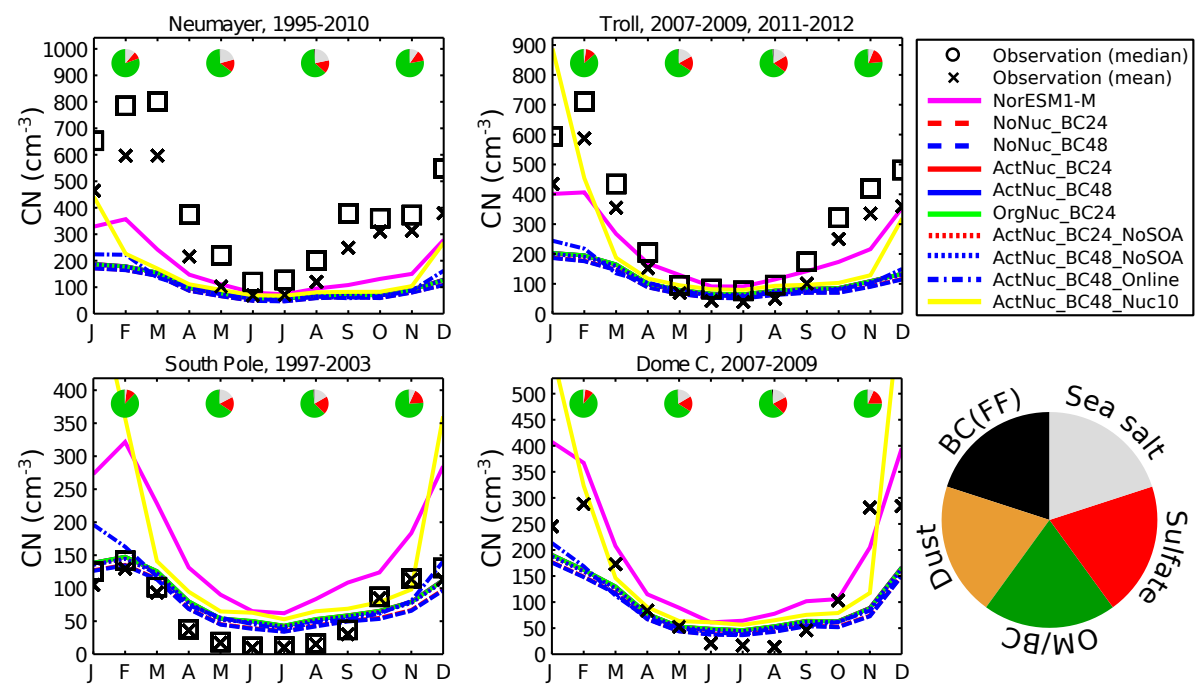

Figure 7. As Fig. 5, but for Antarctic sites.

to doubling of $\mathrm{BC}$ emission size. Again, it is important to remember that the anthropogenic emissions, such as fossil fuel $\mathrm{BC}$, do not include any intra-annual cycle, which can affect the resulting correlation. Although Fig. 2 shows the strong effect from nucleation itself, the performance of activation-type and organic nucleation are rather similar, resulting in a bias of $+20 \%$ and correlation coefficients of 0.39 (OrgNuc_BC24) and 0.40 (ActNuc_BC24).

Simulations without nucleation lead to a low bias of -64 and $-27 \%$ and the smallest correlation coefficients of 0.35 and 0.30 for NoNuc_BC48 and NoNuc_BC24, respectively. Turning on nucleation in the simulations reduces the bias to -5 and $+20 \%$ and increases the correlation coefficient to 0.41 and 0.40 for ActNuc_BC48 and ActNuc_BC24, respectively. Averaged over all stations, SOA formation does not have a large effect on the seasonal cycle: the mean (median) $R^{2}$ is $0.42(0.42)$ and $0.41(0.43)$ with ActNuc_BC48_NoSOA and ActNuc_BC48, respectively. However, with large BC emission size, simulations without SOA formation clearly underestimate the observed number concentrations.

Although the mean bias of $+33 \%$ for the original NorESM1-M setup indicates clear overestimation of aerosol number, the number of stations with a bias between $-30 \%$ and $+30 \%$ is almost identical (28-29) in NorESM1-M, OrgNuc_BC24, ActNuc_BC24 and ActNuc_BC48. On the other hand, the median bias calculated over all ten experiments exceeds $+30 \%$ at 12 stations and is below $-30 \%$ at 21 stations. While there are more stations where NorESM underestimates aerosol number concentrations, the overestimations for certain stations are considerable. Averaging over all stations in the Northern Hemisphere, all model experiments generally underestimate aerosol number concentrations during October-May and overestimate in the summer time.
There are several stations where the correlation between observed and measured monthly averages is poor $\left(R^{2}<0.1\right)$ : Botsalano, Marikana, Mace Head, Cape Grim, K-Puszta, Trinidad Head and Lulin. At all of these stations except Trinidad Head and Marikana, the $R^{2}$ also varies less than 0.07 between experiments. It is clear that the performed simulations and sensitivity experiments cannot capture the uncertainties related to the discrepancy between model and observations. On the other hand, there are locations where the $R^{2}$ varies more than 0.5 between simulations: Indian Himalaya, Bondville, Sable Island, Utö and Thompson Farm.

\subsection{Campaign observations}

Langley et al. (2010) presented aerosol number and CCN concentrations from ship cruises in the North Pacific Ocean. The average aerosol number concentration observed between 9 and 27 July 2002 was $500 \mathrm{~cm}^{-3}$, which is close to the July average of $575 \mathrm{~cm}^{-3}$ found in the ActNuc_BC48 simulation. Rissler et al. (2006) investigated results from the LBA-SMOCC campaign in Amazon, Brazil. Total aerosol number concentrations of $11440 \pm 6790,5550 \pm 3170$ and $2070 \pm 1790 \mathrm{~cm}^{3}$ were found for dry (11 September8 October), transition (9-30 October) and wet season (31 October-14 November), respectively. The corresponding simulated concentrations from the ActNuc_BC48 simulation are 24000,6000 and $2600 \mathrm{~cm}^{3}$. Although the dry season number concentration is overestimated by the model, the transition to wet season is well reproduced.

\subsection{Vertical observations}

The vertical aerosol number concentrations profiles are compared against Clarke and Kapustin (2010) in Fig. 12. The comparison covers 12 flight campaigns over Asia, the Pacific 

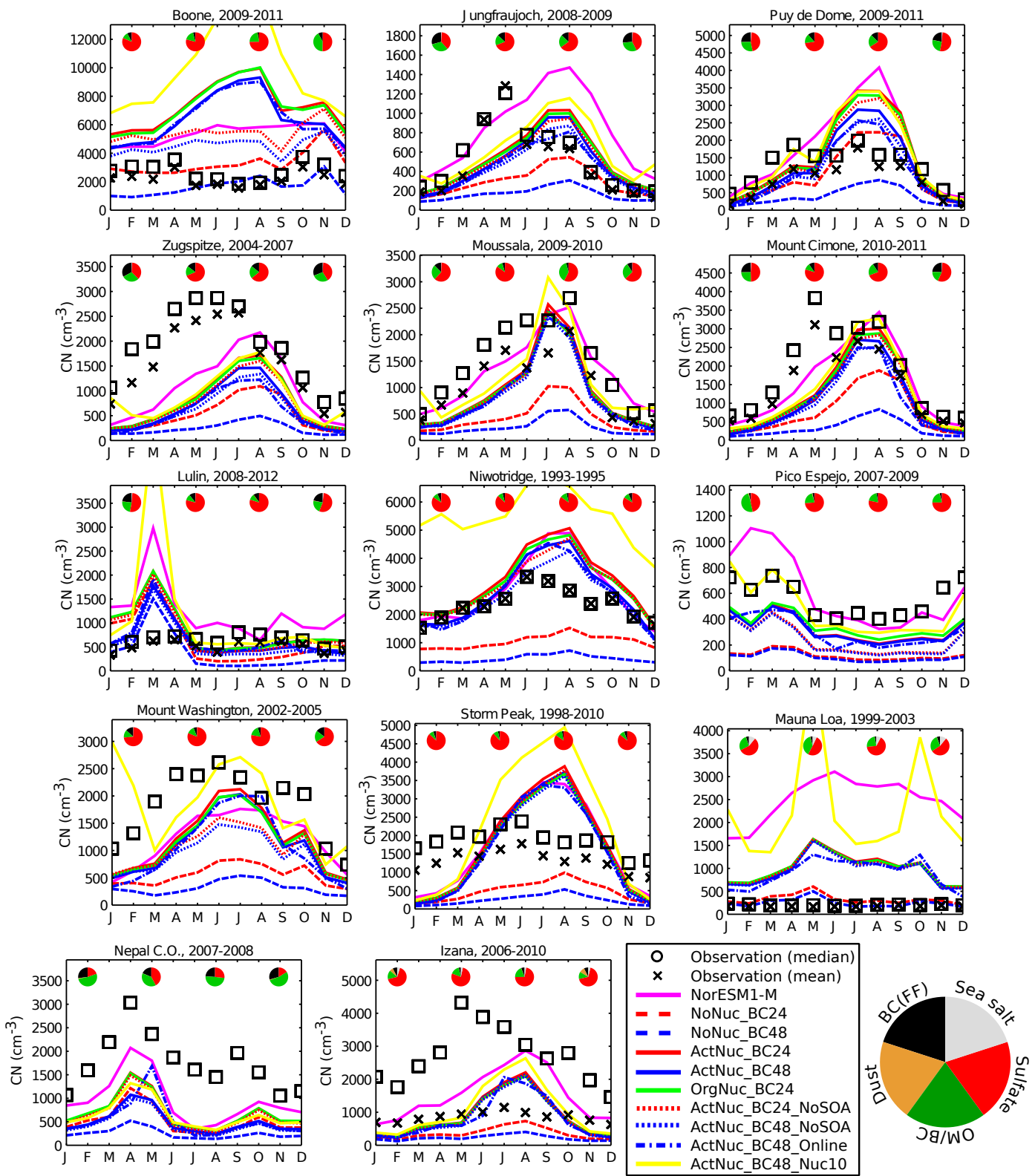

Figure 8. As Fig. 5, but for high-altitude sites (over $1000 \mathrm{~m}$ a.s.1.).

Ocean, the Arctic, North America and the Atlantic. The areas are shown in Fig. 4.

In Asian (ACE-Asia, TRACE-P) and North American (INTEX-A) outflow regions the shape of the vertical profile and the number concentrations are well simulated, with a steep gradient between the surface and $3 \mathrm{~km}$ altitude. Even with a factor of 3 difference in simulated concentrations, NorESM underestimates the observed high concentrations below $1 \mathrm{~km}$ altitude in TRACE-P and INTEX-A. Although the high mean concentrations at low altitudes in TRACE-P and INTEX-A are not captured, the median vertical profiles in the three regions including ACE-Asia are well simulated. In ACE-Asia, including nucleation or using small BC par- ticle size leads to a slight overestimation of particle number above $3 \mathrm{~km}$. In TRACE-P and INTEX-A, the simulations are generally within one standard deviation of observations. In these three regions, the observed increase in concentrations with altitude above $4-5 \mathrm{~km}$ is successfully simulated only for INTEX-A, and to some extent for TRACE-P in simulations with smaller diameter for nucleated particles (ActNuc_BC48_Nuc10).

The observed gradient between 3 and $6 \mathrm{~km}$ in ACE- 1 is reproduced by NorESM, even though the concentrations are generally underestimated. The simulated low-level concentrations are greatly affected by continental Australian emissions, which are not sampled during ACE-1 flights. NorESM 

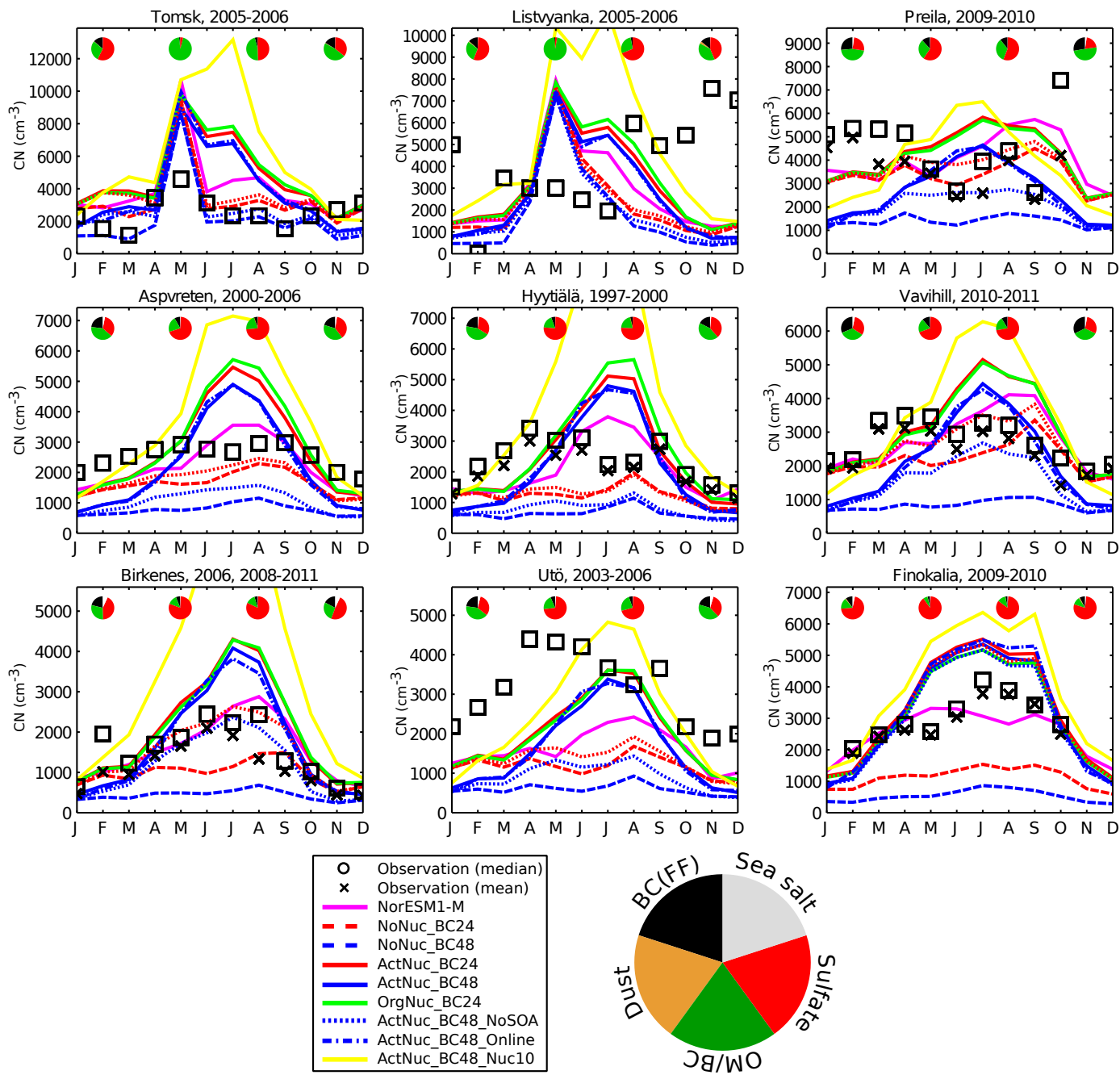

Figure 9. As Fig. 5, but for remote sites.

fails to reproduce the steep gradient in the free troposphere over the Pacific Ocean (PEMT-A and PEMT-B), where observations show aerosol concentrations increasing by a factor of 2-5 between 1 and $8 \mathrm{~m}$. Only the experiment with increased sensitivity to nucleation (ActNuc_BC48_Nuc10) shows some increase in concentration with altitude above $4 \mathrm{~km}$. However, ActNuc_BC48_Nuc10 clearly overestimates concentrations below $3 \mathrm{~km}$ in PEMT-B. The simulated peak between 1 and $2 \mathrm{~km}$ in PEMT-A originates from South American OC emissions and is not visible in averaged observed concentrations. However, the observed variation in PEMTA is large (Clarke and Kapustin, 2010). North of PEMT-A and PEMT-B, the region of INTEX-B Hawaii receives significant concentrations via long-range transport from both Asia and North America, which is visible also in Fig. 1. Even though the amount of observed profiles in INTEX-B Hawaii is the lowest of Clarke and Kapustin (2010), the concentrations around Hawaii are rather well simulated.
Further north over the Pacific Ocean are the INTEX-B Alaska and more continentally influenced IMPEX profiles. Observations in both INTEX-B Alaska and IMPEX show a steep gradient between surface and 3-6 km altitude. Although simulations are in the uncertainty range of observations, NorESM has difficulty in reproducing the observed profile in either region. In IMPEX, nucleation and SOA formation increase particle number concentrations at $0-2 \mathrm{~km}$ altitude by as much as 250 and $50 \%$, respectively, but the model still underestimates the observed concentrations. In both INTEX-B and IMPEX, decreased nucleation-mode size (ActNuc_BC48_Nuc10) increases number concentrations below $2 \mathrm{~km}$, but the model still likely underestimates surface sources. In INTEX-B Alaska, the simulated profile is dominated by long-range transport from Asia and is almost the opposite of the observed profile. The ARCTAS campaign region is located just north of INTEX-B Alaska. NorESM simulates rather well the observed concentrations increasing with altitude in ARCTAS, although 
Table 4. Description of surface sites used in the model evaluation. Source of data: EBAS (E), WDCA (W), NOAA (N), Spracklen et al. (2010) $(\mathrm{S})$, published data $(\mathrm{P})$. The minimum cut-off diameter $\mathrm{dp}_{\mathrm{cut}}$ as well as covered measurement years are indicated for each station.

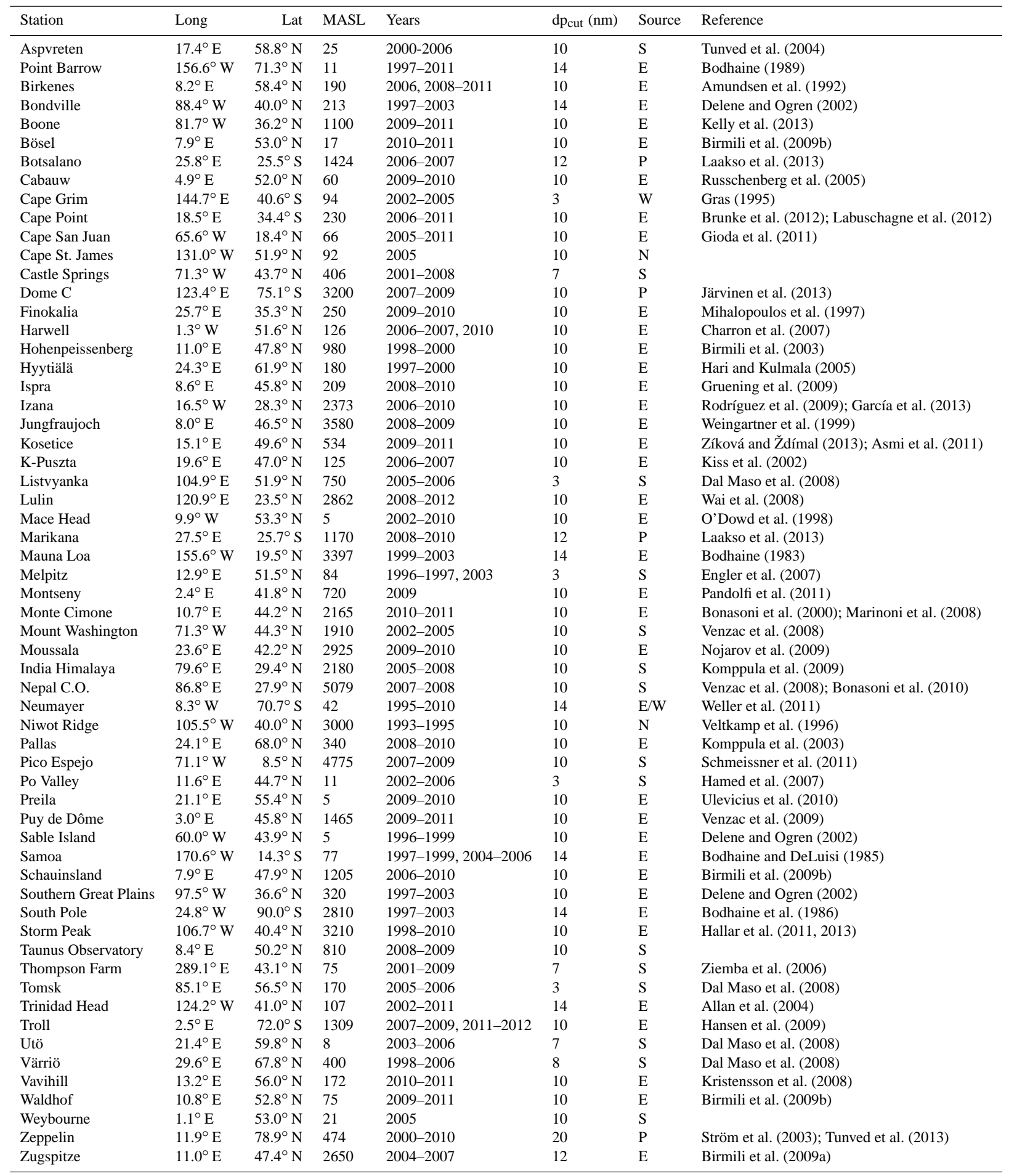

all experiments likely underestimate the observed concentrations. The original NorESM1-M performs best in terms of concentration gradient and absolute concentrations. The study region of ARCTAS contains the Barrow station, which shows concentrations of 170 and $240 \mathrm{~cm}^{-3}$ in March and April, respectively (Fig. 5). The March concentration in Barrow is well simulated in all experiments, but the April concentration is overestimated by the NorESM1-M simulation. 

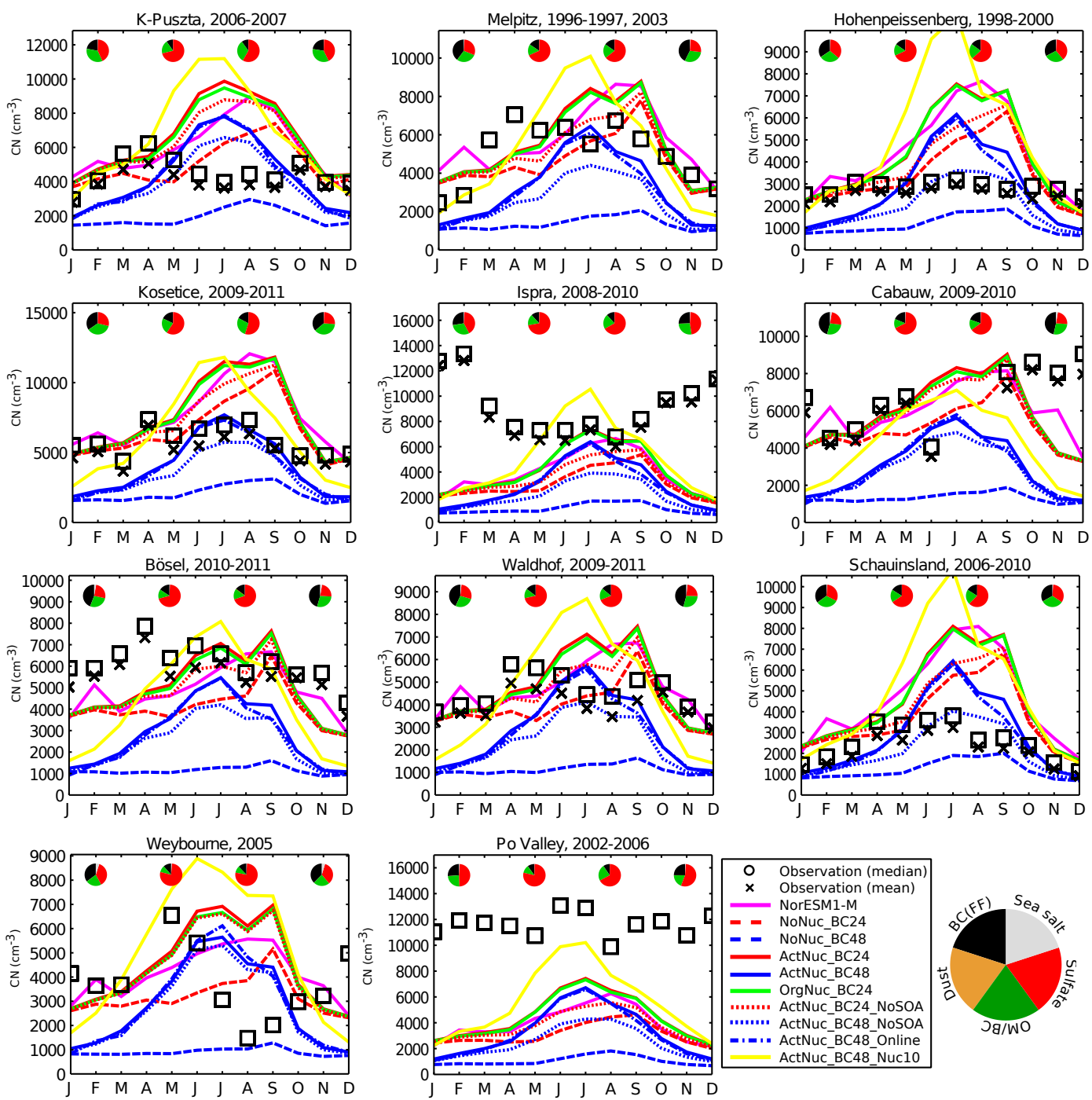

Figure 10. As Fig. 5, but for rural sites.

The MIRAGE and INTEX-B Houston observations cover a similar area around Mexico, and show high concentrations (e.g. from Mexico City) near surface as well as above $2 \mathrm{~km}$ altitude. The model shows high concentrations near surface (over $4000 \mathrm{~cm}^{-3}$ ), but is still underestimating the observed values. Only the original NorESM1-M can reproduce the observed maxima around 3-4 km to some extent. It should be kept in mind that the NorESM profiles are monthly averages.

Overall, most simulations produce similar shapes of vertical profiles for the cases studied here. Eighty per cent of the simulated concentrations are within one standard deviation of measured concentrations; however, the model is generally biased low. Nucleation is relatively efficient in increasing number concentrations near surface (below $2 \mathrm{~km}$ ) and in the upper troposphere. Nucleation can increase concentrations near surface by a factor of 5 at INTEX-A, MIRAGE and INTEX-B Houston (ActNuc_BC48 vs. NoNuc_BC48).
The increase in number concentration due to nucleation at $8 \mathrm{~km}$ altitude ranges from $+50 \%$ at INTEX-B Hawaii and ACE-Asia to $+400 \%$ at INTEX-A.

The sensitivity simulations for the assumption of BC particle size apply only to fossil fuel emission diameter. Hence, the effect of BC particle size is large close to surface near emission sources and higher up in the atmosphere of main transport regions. Indeed, decreasing the $\mathrm{BC}$ particle size from $24 \mathrm{~nm}$ to $12 \mathrm{~nm}$ (ActNuc_BC24 vs. ActNuc_BC48) doubles the near-surface $(0-1 \mathrm{~km})$ particle number concentrations in ACE-Asia and TRACE-P. Transported BC particles are important in ARCTAS, INTEX-B Hawaii and INTEX-B Alaska, where the decrease in BC particle size increases number concentrations by $25 \%$ (at $5 \mathrm{~km}$ ), $30 \%$ (at $2 \mathrm{~km}$ ) and $25 \%$ (at $4 \mathrm{~km}$ ), respectively. In other regions, the effect of $\mathrm{BC}$ size is rather insignificant. 

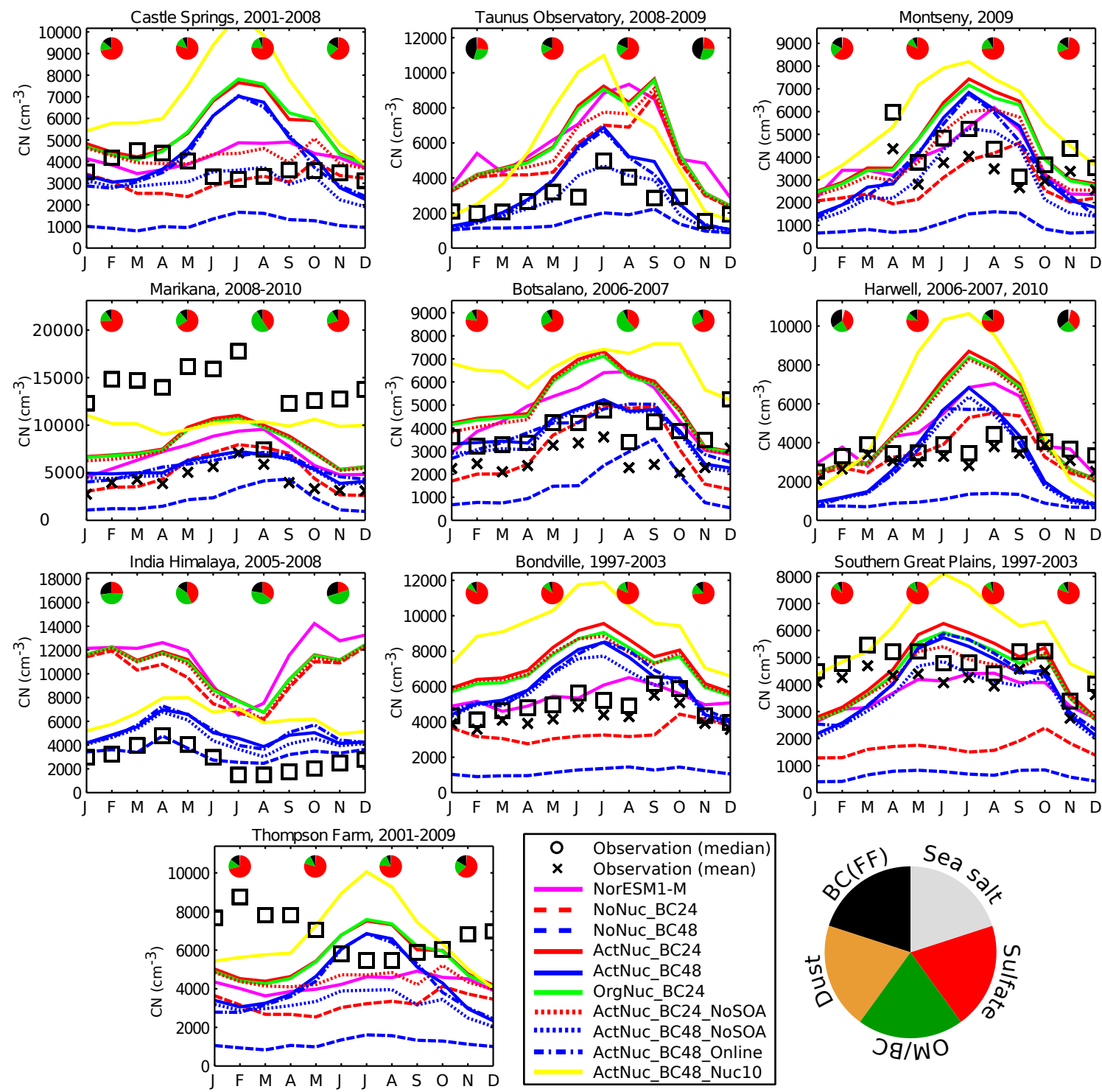

Figure 11. As Fig. 5, but for rural sites (continued from Fig. 10).

With the current implementation of SOA formation mechanism, the effect of SOA on number concentrations in Fig. 12 is generally below $50 \%$. With SOA precursor emissions in a region with significant nucleation, the organic vapours can greatly increase particle survival rates. Fig. 2 shows rather high sensitivity of number concentration to SOA formation in the region of ARCTAS. However, the ARCTAS campaign was conducted in March-April, when the BVOC emissions are rather low. The effect of SOA formation is $15-30 \%$ below $1 \mathrm{~km}$ in ARCTAS, 5-8\% between 2 and $8 \mathrm{~km}$. Due to transport from South America to the region of PEMT-B, the effect of SOA can be seen to be increasing with altitude, reaching a maximum of $15 \%$ at $8 \mathrm{~km}$.

\subsection{Number concentration over oceans}

Figure 13 shows the comparison of remote ocean number concentrations from NorESM against the data set compiled by Heintzenberg et al. (2000). Even over remote ocean areas, the simulated concentrations are very sensitive to nucleation and $\mathrm{BC}$ size. SOA formation has virtually no impact in simulations without nucleation, but in simulations with nucleation the SOA formation increases number concentrations by $15-20 \%$. All simulations fail to match even the observed uncertainty range between $40-20^{\circ} \mathrm{S}$, which could be due to coastal influence in the observations (South Africa, Australia). Also, the concentrations near the Antarctic are somewhat low compared to observations, which was also observed in the Neumayer and Troll stations. The underestimation in 

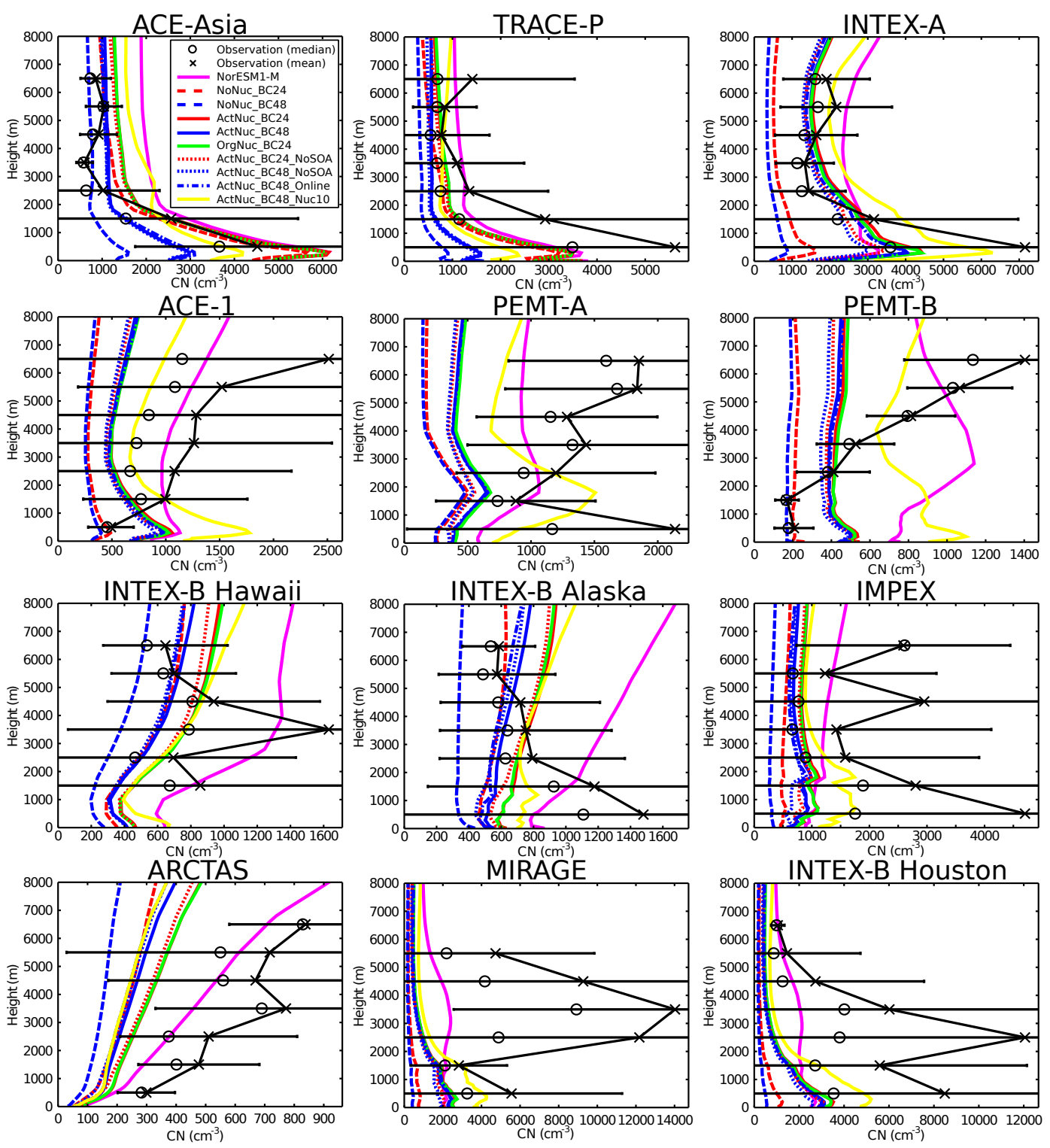

Figure 12. Comparison of NorESM aerosol number concentrations against flight observations compiled by Clarke and Kapustin (2010). The observed mean values (black crosses) are surrounded by one standard deviation, and observed median value is denoted by black circles. Line colouring is explained in legend in top-left panel.

the Southern Hemisphere and overestimation in the Northern Hemisphere was also found in Spracklen et al. (2010).

\section{Conclusions}

The Norwegian Earth System Model, NorESM1-M, was evaluated against atmospheric observations of aerosol number concentration. The measurement data consisted of 60 stations with varying data amounts, flight observation campaigns, individual measurement campaigns and a compilation of marine aerosol concentrations. The observed monthly average number concentrations ranged from $10 \mathrm{~cm}^{-3}$ near the South Pole to over $10000 \mathrm{~cm}^{-3}$ in polluted environments.

The aerosol module in NorESM1-M was further developed to improve the representation of atmospheric nucleation and SOA formation. Evaluating NorESM against site observations revealed information on the relative importance of several processes contributing to aerosol number concentrations. Simulations with nucleation switched off showed a large negative bias $(-64 \%$, NoNuc_BC48). The bias can be reduced (to $-26 \%$, NoNuc_BC24) by adjusting the size of emitted fossil fuel BC primary diameter from 47.2 to $23.6 \mathrm{~nm}$. However, this adjustment degrades the simulated seasonal cycle ( $R^{2}$ decreases from 0.34 to 0.29 ). Introducing 


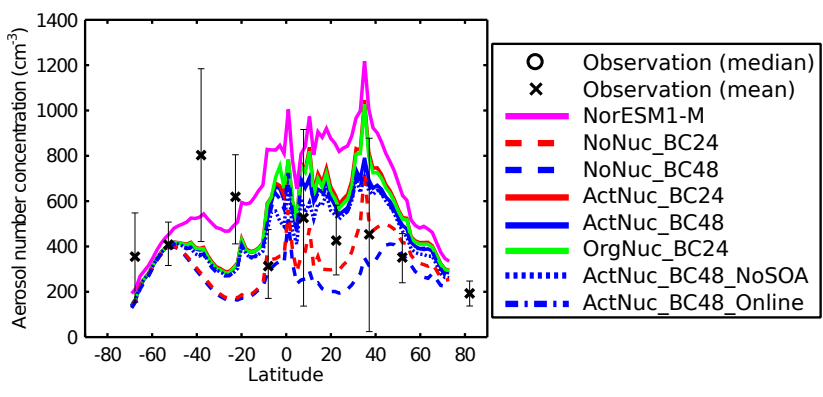

Figure 13. Comparison of NorESM simulations against the data set compiled by Heintzenberg et al. (2000). The model data is masked to include only remote oceans (see Supplement Fig. S1).

explicit nucleation parameterizations in the model improves both seasonal cycle $\left(R^{2}=0.40-0.42\right)$ and model bias (to $-5-21 \%)$. Although generally overestimating observed concentrations (bias $=+33 \%$ ), the aerosol microphysics in the original NorESM1-M reproduced the seasonal cycle rather well $\left(R^{2}=0.37\right)$.

Considering the difficulties in modelling the dynamics of aerosol population in a global climate model, the NorESM performs well compared to several other models (Spracklen et al., 2010; Makkonen et al., 2012a) with global median correlation coefficient of $R^{2}=0.40$ and bias $=-6 \%$ in the ActNuc_BC48 simulation. Coupling aerosols to model physics affected the atmospheric circulation, resulting in somewhat improved results $\left(R^{2}=0.42\right)$. However, the model has clear difficulties in explaining number concentrations in certain locations. A dominant problem of the model is overestimation of the seasonal variation over continents, which is possibly both due to overestimated sensitivity to biogenic emissions and underestimated sink for condensing vapours and small nuclei.

Comparison to vertical observations showed that NorESM can reproduce the vertical profiles in continental outflow regions and in the Arctic, but concentrations near pollution sources or in the free troposphere over the remote Pacific Ocean are not well captured. A more detailed study on simulated vertical profiles is under preparation.

There are several limitations in the evaluation approach which prevent a detailed quantitative validation of model performance. The atmospheric model in NorESM is not nudged against observed reanalysis meteorology, hence the simulated atmospheric circulation can be substantially different from the actual atmosphere during the observations. To approach this problem we performed a sensitivity simulation with a different atmospheric circulation, although this can only provide a limited estimate of uncertainty from model meteorology. In order to minimize the effect of circulation, we have averaged the aerosol observation data over several years where available.

The spatial resolution of the model poses a problem when comparing to point observations: the model grid boxes are
$210 \times 280 \mathrm{~km}$ at the Equator. The model can therefore not take into account e.g. complex topography around measurement sites. Also, the 60 stations included in the study present varying degrees of spatial footprint: some stations are strongly influenced by local point sources, while others are surrounded by rather homogeneous environment. Some of the local source effects could be removed by e.g. filtering out aerosol observation from certain wind sectors, which was not accounted for in this study.

One inherent model deficiency is the lack of intra-annual variation in the anthropogenic aerosol and precursor emissions in most global emission inventories (e.g. AeroCom). which could have a significant effect on aerosol number concentrations on some of the studied stations. The applied emissions are for the year 2000, and might not adequately represent the actual emissions during the observations.

Although the study was able to utilize aerosol observation data from 60 stations with varying amount of data, the role of long-term aerosol measurements for model evaluation remains critical. In many cases a point-by-point comparison between a global aerosol model and observation is not feasible, which limits the applicability of campaign data for model evaluation. Also, the airborne observations of aerosol vertical profiles are extremely useful when analysing the overall performance of model transport coupled with aerosol microphysics.

\section{The Supplement related to this article is available online at doi:10.5194/acp-14-5127-2014-supplement.}

Acknowledgements. R. M. acknowledges CRAICC and EU FP7 project BACCHUS (project number 603445) for financial support. The authors wish to thank the CRAICC project for facilitating the co-operation leading to this article. The work by T. I., A. K., $\varnothing$. S. and J. E. K. has been supported by the Research Council of Norway through the NorClim, EarthClim (207711/E10) and NOTUR/NorStore projects. The work by A. K. has also been supported by the Norwegian Space Centre through the project PM-VRAE. Additionally, T. I., A. K., and Ø. S. acknowledge support through the EU projects PEGASOS and ACCESS. This study was supported by the Norwegian Research Council's Programme for Supercomputing (NOTUR) through a grant of computing time. We are grateful to NCAR and the development teams for CCSM4 and CESM1 for access to their model code. Technical assistance on NorESM from Kari Alterskjær is acknowledged.

The authors wish to acknowledge the EBAS (http://ebas.nilu. no), NOAA (ftp://ftp.cmdl.noaa.gov/aerosol), WDCA (http://www. gaw-wdca.org) data bases, and especially the individual institutions for submitting aerosol data to these data bases. Below are acknowledgements for each station that provided data to this study through the above data bases.

Monte Cimone: A. Marinoni and P. Bonasoni, Institute of Atmospheric Sciences and Climate of the Italian National Research Council, Italy. 
Bösel, Waldhof: W. Birmili, Leibniz Institute for Tropospheric Research, Germany.

Hohenpeissenberg: H. Flentje, German Weather Service (DWD), Germany.

Schauinsland: F. Meinhardt, Federal Environment Agency (UBA), Germany.

Zugspitze: L. Ries, Federal Environment Agency (UBA), Germany. Troll: C. Lunder, Norwegian Institute for Air Research, Norway. Cape Point: C. Labuschagne, South African weather service, South Africa.

Storm Peak: G. Hallar, Desert Research Institute, USA.

Mace Head: C. O'Dowd, Department of Experimental Physics, National University of Ireland.

Moussala: C. Angelov, Institute for Nuclear Research and Nuclear Energy, Bulgaria.

Ispra: J.-P. Putaud, Joint Research Centre, Italy.

Zeppelin: J. Ström, Stockholm University, Sweden.

Barrow, Bondville, Mauna Loa, Sable, Samoa, SGP, South Pole, Trinidad Head, Niwot Ridge: J. A. Ogren, National Oceanic and Atmospheric Administration, USA.

Cape Grim: J. Gras, CSIRO Atmospheric Research, Australia. The Cape Grim Program and Global Atmospheric Watch are acknowledged.

Puy de Dôme: K. Sellegri, National Center for Scientific Research, France. Observatoire de Physique du Globe (OPGC) is acknowledged.

Cabauw: B. Henzing and M. Marcel, Netherlands Organisation for Applied Scientific Research, TNO.

Hyytiälä, Pallas: M. Kulmala, University of Helsinki, Finland.

K-Puszta: M. Kulmala, University of Helsinki, Finland. Hungarian Meteorological Service is acknowledged.

Birkenes: M. Fiebig, Norwegian Institute for Air Research.

Finokalia: N. Mihalopoulos, University of Crete, Greece.

Vavihill: E. Swietlicki, Lund University, Sweden.

Cape San Juan: O. L. Mayol-Bracero, University of Puerto Rico Rio Piedras.

Harwell: R. Harrison, University of Birmingham, United Kingdom. Neumayer: R. Weller, Alfred Wegener Institute, Germany.

Izana: R. Sergio, Agencia Estatal de Meteorología, Izana Atmospheric Research Center, Spain.

Boone: J. Sherman, Appalachian State University, USA.

Preila: V. Ulevicius, Center for Physical Sciences and Technology, Lithuania.

Jungfraujoch: U. Baltensperger, Paul Scherrer Institute, Switzerland.

Montseny: A. Alastuey, Institute of Environmental Assessment and Water Research, Consejo Superior de Investigaciones Científicas, Barcelona, Spain.

Kosetice: Z. Vladimir, Institute of Chemical Process Fundamentals, Czech Republic.

Lulin: N.-H. Lin, National Central University, Taiwan. Taiwan EPA is acknowledged.

The German Federal Environment Agency (UBA), and the German Ultrafine Aerosol Network (GUAN, coordinated by W. Birmili) are acknowledged.

Measurements at Bösel, Waldhof, Schauinsland, and Zugspitze were supported by the German Federal Environment Ministry (BMU) grant F\&E 370343200 (German title: "Erfassung der Zahl feiner und ultrafeiner Partikel in der Außenluft"), 2008-2010.
This work was carried out with the support of the FP6 European Commission project European Supersites for Atmospheric Aerosol Research, EUSAAR, contract no. RII3-CT-2006-026140, the European Seventh Framework Program, "ACTRIS, Aerosols, Clouds, and Trace gases Research Infra Structure Network".

Edited by: H. Järvinen

\section{References}

Abdul-Razzak, H. and Ghan, S. J.: A parameterization of aerosol activation 2. Multiple aerosol types, J. Geophys. Res., 105, 68376844, 2000.

Adams, P. and Seinfeld, J.: Predicting global aerosol size distributions in general circulation models, J. Geophys. Res.-Atmos., 107, 4-1-4-23, doi:10.1097/00132985-200204000-00004, 2002.

Allan, J., Bower, K., Coe, H., Boudries, H., Jayne, J., Canagaratna, M., Millet, D., Goldstein, A., Quinn, P., Weber, R., and Worsnop, D.: Submicron aerosol composition at Trinidad Head, California, during ITCT 2K2: Its relationship with gas phase volatile organic carbon and assessment of instrument performance, J. Geophys. Res., 109, D23S24, doi:10.1029/2003JD004208, 2004.

Amundsen, C., Hanssen, J., Semb, A., and Steinnes, E.: Long-range atmospheric transport of trace elements to southern Norway, Atmos. Environ., 26, 1309-1324, 1992.

Anenberg, S., Schwartz, J., Shindell, D., Amann, M., Faluvegi, G., Klimont, Z., Janssens-Maenhout, G., Pozzoli, L., van Dingenen, R., Vignati, E., Emberson, L., Muller, N., Jason West, J., Williams, M., Demkine, V., Kevin Hicks, W., Kuylenstierna, J., Raes, F., and Ramanathan, V.: Global air quality and health cobenefits of mitigating near-term climate change through methane and black carbon emission controls, Environ. Health Persp., 120, 831-839, doi:10.1289/ehp.1104301, 2012.

Anttila, T., Kerminen, V.-M., and Lehtinen, K.: Parameterizing the formation rate of new particles: The effect of nuclei self-coagulation, J. Aerosol Sci., 41, 621-636, doi:10.1016/j.jaerosci.2010.04.008, 2010.

Asmi, A., Wiedensohler, A., Laj, P., Fjaeraa, A.-M., Sellegri, K., Birmili, W., Weingartner, E., Baltensperger, U., Zdimal, V., Zikova, N., Putaud, J.-P., Marinoni, A., Tunved, P., Hansson, H.C., Fiebig, M., Kivekäs, N., Lihavainen, H., Asmi, E., Ulevicius, V., Aalto, P. P., Swietlicki, E., Kristensson, A., Mihalopoulos, N., Kalivitis, N., Kalapov, I., Kiss, G., de Leeuw, G., Henzing, B., Harrison, R. M., Beddows, D., O’Dowd, C., Jennings, S. G., Flentje, H., Weinhold, K., Meinhardt, F., Ries, L., and Kulmala, M.: Number size distributions and seasonality of submicron particles in Europe 2008-2009, Atmos. Chem. Phys., 11, 5505-5538, doi:10.5194/acp-11-5505-2011, 2011.

Bentsen, M., Bethke, I., Debernard, J. B., Iversen, T., Kirkevåg, A., Seland, Ø., Drange, H., Roelandt, C., Seierstad, I. A., Hoose, C., and Kristjánsson, J. E.: The Norwegian Earth System Model, NorESM1-M - Part 1: Description and basic evaluation of the physical climate, Geosci. Model Dev., 6, 687-720, doi:10.5194/gmd-6-687-2013, 2013.

Birmili, W., Berresheim, H., Plass-Dülmer, C., Elste, T., Gilge, S., Wiedensohler, A., and Uhrner, U.: The Hohenpeissenberg aerosol formation experiment (HAFEX): a long-term study including size-resolved aerosol, $\mathrm{H}_{2} \mathrm{SO}_{4}, \mathrm{OH}$, and monoter- 
penes measurements, Atmos. Chem. Phys., 3, 361-376, doi:10.5194/acp-3-361-2003, 2003.

Birmili, W., Ries, L., Sohmer, R., Anastou, A., Sonntag, A., König, K., and Levin, I.: Fine and ultrafine aerosol particles at the GAW station Schneefernerhaus/Zugspitze, Gefahrstoffe Reinhalt. L., 69, 31-35, 2009a.

Birmili, W., Weinhold, K., Nordmann, S., Wiedensohler, A., Spindler, G., Müller, K., Herrmann, H., Gnauk, T., Pitz, M., Cyrys, J., Flentje, H., Nickel, C., Kuhlbusch, T., Löschau, G., Haase, D., Meinhardt, F., Schwerin, A., Ries, L., and Wirtz, K.: Atmospheric aerosol measurements in the German Ultrafine Aerosol Network (GUAN) - Part 1: Soot and particle number size distributions, Gefahrstoffe Reinhalt. L., 69, 137-145, 2009b.

Bodhaine, B.: Aerosol measurements at four background sites ( Barrow Alaska, Mauna Loa, Hawaii, American Samoa, South Pole)., J. Geophys. Res., 88, 10735-10768, 1983.

Bodhaine, B.: Barrow surface aerosol: 1976-1986, Atmos. Environ., 23, 2357-2369, 1989

Bodhaine, B. and DeLuisi, J.: An aerosol climatology of Samoa, J. Atmos. Chem., 3, 107-122, doi:10.1007/BF00049371, 1985.

Bodhaine, B., Deluisi, J., and Harris, J.: Aerosol measurements at the South Pole, Tellus, 38, 223-235, 1986.

Bonasoni, P., Stohl, A., Cristofanelli, P., Calzolari, F., Colombo, T., and Evangelisti, F.: Background ozone variations at Mt. Cimone Station, Atmos. Environ., 34, 5183-5189, 2000.

Bonasoni, P., Laj, P., Marinoni, A., Sprenger, M., Angelini, F., Arduini, J., Bonafè, U., Calzolari, F., Colombo, T., Decesari, S., Di Biagio, C., di Sarra, A. G., Evangelisti, F., Duchi, R., Facchini, MC., Fuzzi, S., Gobbi, G. P., Maione, M., Panday, A., Roccato, F., Sellegri, K., Venzac, H., Verza, GP., Villani, P., Vuillermoz, E., and Cristofanelli, P.: Atmospheric Brown Clouds in the Himalayas: first two years of continuous observations at the Nepal Climate Observatory-Pyramid (5079 m), Atmos. Chem. Phys., 10, 7515-7531, doi:10.5194/acp-10-7515-2010, 2010.

Bond, T. C., Doherty, S. J., Fahey, D. W., Forster, P. M., Berntsen, T., DeAngelo, B. J., Flanner, M. G., Ghan, S., Kärcher, B., Koch, D., Kinne, S., Kondo, Y., Quinn, P. K., Sarofim, M. C., Schultz, M. G., Schulz, M., Venkataraman, C., Zhang, H., Zhang, S., Bellouin, N., Guttikunda, S. K., Hopke, P. K., Jacobson, M. Z., Kaiser, J. W., Klimont, Z., Lohmann, U., Schwarz, J. P., Shindell, D., Storelvmo, T., Warren, S. G., and Zender, C. S.: Bounding the role of black carbon in the climate system: A scientific assessment, J. Geophys. Res.-Atmos., 118, 5380-5552, doi:10.1002/jgrd.50171, 2013.

Boy, M., Kazil, J., Lovejoy, E., Guenther, A., and Kulmala, M.: Relevance of ion-induced nucleation of sulfuric acid and water in the lower troposphere over the boreal forest at northern latitudes, Atmos. Res., 90, 151-158, doi:10.1016/j.atmosres.2008.01.002, 2008

Brunke, E.-G., Ebinghaus, R., Kock, H. H., Labuschagne, C., and Slemr, F.: Emissions of mercury in southern Africa derived from long-term observations at Cape Point, South Africa, Atmos. Chem. Phys., 12, 7465-7474, doi:10.5194/acp-12-74652012, 2012.

Charron, A., Birmili, W., and Harrison, R.: Factors influencing new particle formation at the rural site, Harwell, United Kingdom, J. Geophys. Res.-Atmos., 112, D14210, doi:10.1029/2007JD008425, 2007.
Clarke, A. and Kapustin, V.: Hemispheric aerosol vertical profiles: Anthropogenic impacts on optical depth and cloud nuclei, Science, 329, 1488-1492, doi:10.1126/science.1188838, 2010.

Dal Maso, M., Sogacheva, L., Anisimov, M., Arshinov, M., Baklanov, A., Belan, B., Khodzher, T., Obolkin, V., Staroverova, A., Vlasov, A., Zagaynov, V., Lushnikov, A., Lyubovtseva, Y., Riipinen, I., Kerminen, V.-M., and Kulmala, M.: Aerosol particle formation events at two Siberian stations inside the boreal forest, Boreal Environ. Res., 13, 81-92, 2008.

Delene, D. and Ogren, J.: Variability of aerosol optical properties at four North American surface monitoring sites, J. Atmos. Sci., 59, 1135-1150, 2002.

Dentener, F., Kinne, S., Bond, T., Boucher, O., Cofala, J., Generoso, S., Ginoux, P., Gong, S., Hoelzemann, J. J., Ito, A., Marelli, L., Penner, J. E., Putaud, J.-P., Textor, C., Schulz, M., van der Werf, G. R., and Wilson, J.: Emissions of primary aerosol and precursor gases in the years 2000 and 1750 prescribed data-sets for AeroCom, Atmos. Chem. Phys., 6, 4321-4344, doi:10.5194/acp-64321-2006, 2006

Ehn, M., Thornton, J., Kleist, E., Sipilä, M., Junninen, H., Pullinen, I., Springer, M., Rubach, F., Tillmann, R., Lee, B., LopezHilfiker, F., Andres, S., Acir, I.-H., Rissanen, M., Jokinen, T., Schobesberger, S., Kangasluoma, J., Kontkanen, J., Nieminen, T., Kurtén, T., Nielsen, L., Jørgensen, S., Kjaergaard, H., Canagaratna, M., Maso, M., Berndt, T., Petäjä, T., Wahner, A., Kerminen, V.-M., Kulmala, M., Worsnop, D., Wildt, J., and Mentel, T.: A large source of low-volatility secondary organic aerosol, Nature, 506, 476-479, doi:10.1038/nature13032, 2014.

Engler, C., Rose, D., Wehner, B., Wiedensohler, A., Brüggemann, E., Gnauk, T., Spindler, G., Tuch, T., and Birmili, W.: Size distributions of non-volatile particle residuals $\left(D_{p}<800 \mathrm{~nm}\right)$ at a rural site in Germany and relation to air mass origin, Atmos. Chem. Phys., 7, 5785-5802, doi:10.5194/acp-7-5785-2007, 2007.

Forster, P., Ramaswamy, V., Artaxo, P., Berntsen, T., Betts, R., Fahey, D. W., Haywood, J., Lean, J., Lowe, D. C., Myhre, G., Nganga, J., Prinn, R., Raga, G., Schulz, M., and Van Dorland, R.: Climate Change 2007, The Physical Science Basis, Contribution of Working Group I to the Fourth Assessment Report of the Intergovernmental Panel on Climate Change, Cambridge Univ. Press, Cambridge, UK, and New York, NY, USA, 2007.

Fountoukis, C., Riipinen, I., Denier van der Gon, H. A. C., Charalampidis, P. E., Pilinis, C., Wiedensohler, A., O’Dowd, C., Putaud, J. P., Moerman, M., and Pandis, S. N.: Simulating ultrafine particle formation in Europe using a regional CTM: contribution of primary emissions versus secondary formation to aerosol number concentrations, Atmos. Chem. Phys., 12, 86638677, doi:10.5194/acp-12-8663-2012, 2012.

García, M. I., Rodríguez, S., González, Y., and García, R. D.: Climatology of new particle formation events in the subtropical North Atlantic free troposphere at Izaña GAW observatory, Atmos. Chem. Phys. Discuss., 13, 24127-24169, doi:10.5194/acpd-1324127-2013, 2013.

Gaydos, T. M., Stanier, C. O., and Pandis, S. N.: Modeling of in situ ultrafine atmospheric particle formation in the eastern United States, J. Geophys. Res.-Atmos., 110, D07S12, doi:10.1029/2004JD004683, 2005.

Gent, P., Danabasoglu, G., Donner, L., Holland, M., Hunke, E., Jayne, S., Lawrence, D., Neale, R., Rasch, P., Vertenstein, M., Worley, P., Yang, Z., and Zhang, M.: The community 
climate system model version 4, J. Climate, 24, 4973-4991, doi:10.1175/2011JCLI4083.1, 2011.

Ghan, S., Easter, R., Chapman, E., Abdul-Razzak, H., Zhang, Y., Leung, L., Laulainen, N., Saylor, R., and Zaveri, R.: A physically based estimate of radiative forcing by anthropogenic sulfate aerosol, J. Geophys. Res.-Atmos., 106, 5279-5293, 2001.

Gioda, A., Reyes-Rodrìguez, G., Santos-Figueroa, G., Collett Jr., J., Decesari, S., Ramos, M., Bezerra Netto, H., De Aquino Neto, F., and Mayol-Bracero, O.: Speciation of water-soluble inorganic, organic, and total nitrogen in a background marine environment: Cloud water, rainwater, and aerosol particles, J. Geophys. Res.Atmos., 116, D05203, doi:10.1029/2010JD015010, 2011.

Gonzàlez, Y., Rodrìguez, S., Guerra Garcìa, J., Trujillo, J., and Garcìa, R.: Ultrafine particles pollution in urban coastal air due to ship emissions, Atmos. Environ., 45, 4907-4914, doi:10.1016/j.atmosenv.2011.06.002, 2011.

Gras, J. L.: CN, CCN and particle size in Southern Ocean air at Cape Grim, Atmos. Res., 35, 233-251, 1995.

Gruening, C., Adam, M., Cavalli, F., Cavalli, P., Dell'Acqua, A., Martins Dos Santos, S., Pagliari, V., Roux, D., and Putaud, J.-P.: JRC Ispra EMEP GAW Regional Station for Atmos. Res. 2008 Report, Tech. Rep. JRC55382, European Commission, http:// publications.jrc.ec.europa.eu/repository/handle/111111111/538 (last access: 15 January 2014), 2009.

Guenther, A., Karl, T., Harley, P., Wiedinmyer, C., Palmer, P. I., and Geron, C.: Estimates of global terrestrial isoprene emissions using MEGAN (Model of Emissions of Gases and Aerosols from Nature), Atmos. Chem. Phys., 6, 3181-3210, doi:10.5194/acp-63181-2006, 2006.

Hallar, A., Lowenthal, D., Chirokova, G., Borys, R., and Wiedinmyer, C.: Persistent daily new particle formation at a mountain-top location, Atmos. Environ., 45, 4111-4115, doi:10.1016/j.atmosenv.2011.04.044, 2011.

Hallar, A., Lowenthal, D., Clegg, S., Samburova, V., Taylor, N., Mazzoleni, L., Zielinska, B., Kristensen, T., Chirokova, G., McCubbin, I., Dodson, C., and Collins, D.: Chemical and Hygroscopic Properties of Aerosol Organics at Storm Peak Laboratory, J. Geophys. Res.-Atmos., 118, 4767-4779, doi:10.1002/jgrd.50373, 2013.

Hamed, A., Joutsensaari, J., Mikkonen, S., Sogacheva, L., Dal Maso, M., Kulmala, M., Cavalli, F., Fuzzi, S., Facchini, M. C., Decesari, S., Mircea, M., Lehtinen, K. E. J., and Laaksonen, A.: Nucleation and growth of new particles in Po Valley, Italy, Atmos. Chem. Phys., 7, 355-376, doi:10.5194/acp-7-355-2007, 2007

Hansen, G., Aspmo, K., Berg, T., Edvardsen, K., Fiebig, M., Kallenborn, R., Krognes, T., Lunder, C., Stebel, K., Schmidbauer, N., Solberg, S., and Yttri, K.: Atmospheric monitoring at the Norwegian Antarctic station Troll: measurement programme and first results, Polar Res., 28, 353-363, doi:10.1111/j.17518369.2009.00134.x, 2009.

Hari, P. and Kulmala, M.: Station for Measuring EcosystemAtmosphere Relations (SMEAR II), Boreal Environ. Res., 10, 315-322, 2005.

Heintzenberg, J., Covert, D. C., and van Dingenen, R.: Size distribution and chemical composition of marine aerosols: a compilation and review, Tellus, 52, 1104-1122, 2000.

Henne, S., Brunner, D., Folini, D., Solberg, S., Klausen, J., and Buchmann, B.: Assessment of parameters describing representa- tiveness of air quality in-situ measurement sites, Atmos. Chem. Phys., 10, 3561-3581, doi:10.5194/acp-10-3561-2010, 2010.

Hoyle, C. R., Berntsen, T., Myhre, G., and Isaksen, I. S. A.: Secondary organic aerosol in the global aerosol - chemical transport model Oslo CTM2, Atmos. Chem. Phys., 7, 5675-5694, doi:10.5194/acp-7-5675-2007, 2007.

Iversen, T., Bentsen, M., Bethke, I., Debernard, J. B., Kirkevåg, A., Seland, Ø., Drange, H., Kristjansson, J. E., Medhaug, I., Sand, M., and Seierstad, I. A.: The Norwegian Earth System Model, NorESM1-M - Part 2: Climate response and scenario projections, Geosci. Model Dev., 6, 389-415, doi:10.5194/gmd-6-3892013, 2013.

Järvinen, E., Virkkula, A., Nieminen, T., Aalto, P. P., Asmi, E., Lanconelli, C., Busetto, M., Lupi, A., Schioppo, R., Vitale, V., Mazzola, M., Petäjä, T., Kerminen, V.-M., and Kulmala, M.: Seasonal cycle and modal structure of particle number size distribution at Dome C, Antarctica, Atmos. Chem. Phys., 13, 7473-7487, doi:10.5194/acp-13-7473-2013, 2013.

Kelly, G., Taubman, B., Perry, L., Sherman, J., Soulé, P., and Sheridan, P.: Relationships between aerosols and precipitation in the southern Appalachian Mountains, Int. J. Climatol., 33, 30163028, doi:10.1002/joc.3632, 2013.

Kerminen, V. M. and Kulmala, M.: Analytical formulae connecting the "real" and the "apparent" nucleation rate and the nuclei number concentration for atmospheric nucleation events, J. Aerosol Sci., 33, 609-622, 2002.

Keskinen, H., Virtanen, A., Joutsensaari, J., Tsagkogeorgas, G., Duplissy, J., Schobesberger, S., Gysel, M., Riccobono, F., Slowik, J. G., Bianchi, F., Yli-Juuti, T., Lehtipalo, K., Rondo, L., Breitenlechner, M., Kupc, A., Almeida, J., Amorim, A., Dunne, E. M., Downard, A. J., Ehrhart, S., Franchin, A., Kajos, M.K., Kirkby, J., Kürten, A., Nieminen, T., Makhmutov, V., Mathot, S., Miettinen, P., Onnela, A., Petäjä, T., Praplan, A., Santos, F. D., Schallhart, S., Sipilä, M., Stozhkov, Y., Tomé, A., Vaattovaara, P., Wimmer, D., Prevot, A., Dommen, J., Donahue, N. M., Flagan, R.C., Weingartner, E., Viisanen, Y., Riipinen, I., Hansel, A., Curtius, J., Kulmala, M., Worsnop, D. R., Baltensperger, U., Wex, H., Stratmann, F., and Laaksonen, A.: Evolution of particle composition in CLOUD nucleation experiments, Atmos. Chem. Phys. 13, 5587-5600, doi:10.5194/acp-13-5587-2013, 2013.

Kirkevåg, A., Iversen, T., Seland, Ø., Hoose, C., Kristjánsson, J. E., Struthers, H., Ekman, A. M. L., Ghan, S., Griesfeller, J., Nilsson, E. D., and Schulz, M.: Aerosol-climate interactions in the Norwegian Earth System Model - NorESM1-M, Geosci. Model Dev., 6, 207-244, doi:10.5194/gmd-6-207-2013, 2013.

Kiss, G., Varga, B., Galambos, I., and Ganszky, I.: Characterization of water-soluble organic matter isolated from atmospheric fine aerosol, J. Geophys. Res.-Atmos., 107, 8339, doi:10.1029/2001JD000603, 2002.

Komppula, M., Lihavainen, H., Hatakka, J., Paatero, J., Aalto, P., Kulmala, M., and Viisanen, Y.: Observations of new particle formation and size distributions at two different heights and surroundings in subarctic area in northern Finland, J. Geophys. Res. 108, 4295, 10.1029/2002JD00, 2003.

Komppula, M., Lihavainen, H., Hyvärinen, A.-P., Kerminen, V.-M., Panwar, T., Sharma, V., and Viisanen, Y.: Physical properties of aerosol particles at a Himalayan background site in India, J. Geophys. Res.-Atmos., 114, D12202, doi:10.1029/2008JD011007, 2009. 
Kristensson, A., Dal Maso, M., Swietlicki, E., Hussein, T., Zhou, J., Kerminen, V.-M., and Kulmala, M.: Characterization of new particle formation events at a background site in southern Sweden: Relation to air mass history, Tellus B, 60, 330-344, doi:10.1111/j.1600-0889.2008.00345.x, 2008.

Kulmala, M., Lehtinen, K. E. J., and Laaksonen, A.: Cluster activation theory as an explanation of the linear dependence between formation rate of $3 \mathrm{~nm}$ particles and sulphuric acid concentration, Atmos. Chem. Phys., 6, 787-793, doi:10.5194/acp-6-787-2006, 2006

Kulmala, M., Asmi, A., Lappalainen, H. K., Baltensperger, U., Brenguier, J.-L., Facchini, M. C., Hansson, H.-C., Hov, Ø., O'Dowd, C. D., Pöschl, U., Wiedensohler, A., Boers, R., Boucher, O., de Leeuw, G., Denier van der Gon, H. A. C., Feichter, J., Krejci, R., Laj, P., Lihavainen, H., Lohmann, U., McFiggans, G., Mentel, T., Pilinis, C., Riipinen, I., Schulz, M., Stohl, A., Swietlicki, E., Vignati, E., Alves, C., Amann, M., Ammann, M., Arabas, S., Artaxo, P., Baars, H., Beddows, D. C. S., Bergström, R., Beukes, J. P., Bilde, M., Burkhart, J. F., Canonaco, F., Clegg, S. L., Coe, H., Crumeyrolle, S., D'Anna, B., Decesari, S., Gilardoni, S., Fischer, M., Fjaeraa, A. M., Fountoukis, C., George, C., Gomes, L., Halloran, P., Hamburger, T., Harrison, R. M., Herrmann, H., Hoffmann, T., Hoose, C., Hu, M., Hyvärinen, A., Hõrrak, U., Iinuma, Y., Iversen, T., Josipovic, M., Kanakidou, M., Kiendler-Scharr, A., Kirkevåg, A., Kiss, G., Klimont, Z., Kolmonen, P., Komppula, M., Kristjánsson, J.-E., Laakso, L., Laaksonen, A., Labonnote, L., Lanz, V. A., Lehtinen, K. E. J., Rizzo, L. V., Makkonen, R., Manninen, H. E., McMeeking, G., Merikanto, J., Minikin, A., Mirme, S., Morgan, W. T., Nemitz, E., O’Donnell, D., Panwar, T. S., Pawlowska, H., Petzold, A., Pienaar, J. J., Pio, C., Plass-Duelmer, C., Prévôt, A. S. H., Pryor, S., Reddington, C. L., Roberts, G., Rosenfeld, D., Schwarz, J., Seland, Ø., Sellegri, K., Shen, X. J., Shiraiwa, M., Siebert, H., Sierau, B., Simpson, D., Sun, J. Y., Topping, D., Tunved, P., Vaattovaara, P., Vakkari, V., Veefkind, J. P., Visschedijk, A., Vuollekoski, H., Vuolo, R., Wehner, B., Wildt, J., Woodward, S., Worsnop, D. R., van Zadelhoff, G.-J., Zardini, A. A., Zhang, K., van Zyl, P. G., Kerminen, V.-M., S Carslaw, K., and Pandis, S. N.: General overview: European Integrated project on Aerosol Cloud Climate and Air Quality interactions (EUCAARI) - integrating aerosol research from nano to global scales, Atmos. Chem. Phys., 11, 13061-13143, doi:10.5194/acp11-13061-2011, 2011.

Kyrö, E.-M., Kerminen, V.-M., Virkkula, A., Dal Maso, M., Parshintsev, J., Ruíz-Jimenez, J., Forsström, L., Manninen, H. E., Riekkola, M.-L., Heinonen, P., and Kulmala, M.: Antarctic new particle formation from continental biogenic precursors, Atmos. Chem. Phys., 13, 3527-3546, doi:10.5194/acp-13-3527-2013, 2013.

Laakso, L., Merikanto, J., Vakkari, V., Laakso, H., Kulmala, M., Molefe, M., Kgabi, N., Mabaso, D., Carslaw, K. S., Spracklen, D. V., Lee, L. A., Reddington, C. L., and Kerminen, V.-M.: Boundary layer nucleation as a source of new $\mathrm{CCN}$ in savannah environment, Atmos. Chem. Phys., 13, 1957-1972, doi:10.5194/acp13-1957-2013, 2013.

Labuschagne, C., Brunke, E.-G., Beukes, J., van Zyl, P., and Laakso, L.: Aerosols in a coastal environment: What does 6 years of measurements tell us?, South African Society for Atmospheric Sci- ences, Cape Town 28th Annual Conference, 26-27 September 2012, ISBN 978-0-620-53375-1, 2012.

Lamarque, J.-F., Bond, T. C., Eyring, V., Granier, C., Heil, A., Klimont, Z., Lee, D., Liousse, C., Mieville, A., Owen, B., Schultz, M. G., Shindell, D., Smith, S. J., Stehfest, E., Van Aardenne, J., Cooper, O. R., Kainuma, M., Mahowald, N., McConnell, J. R., Naik, V., Riahi, K., and van Vuuren, D. P.: Historical (1850-2000) gridded anthropogenic and biomass burning emissions of reactive gases and aerosols: methodology and application, Atmos. Chem. Phys., 10, 7017-7039, doi:10.5194/acp10-7017-2010, 2010.

Langley, L., Leaitch, W. R., Lohmann, U., Shantz, N. C., and Worsnop, D. R.: Contributions from DMS and ship emissions to CCN observed over the summertime North Pacific, Atmos. Chem. Phys., 10, 1287-1314, doi:10.5194/acp-10-1287-2010, 2010.

Lehtinen, K., Dal Maso, M., Kulmala, M., and Kerminen, V.M.: Estimating nucleation rates from apparent particle formation rates and vice versa: Revised formulation of the Kerminen-Kulmala equation, J. Aerosol Sci., 38, 988-994, doi:10.1016/j.jaerosci.2007.06.009, 2007.

Lohmann, U. and Feichter, J.: Global indirect aerosol effects: a review, Atmos. Chem. Phys., 5, 715-737, doi:10.5194/acp-5-7152005, 2005.

Lucas, D. and Akimoto, H.: Evaluating aerosal nucleation parameterizations in a global atmospheric model, Geophys. Res. Lett. 33, L10808, doi:10.1029/2006GL025672, 2006.

Maier-Reimer, E.: Geochemical cycles in an ocean general circulation model. Preindustrial tracer distributions, Global Biogeochem. Cy., 7, 645-677, doi:10.1029/93GB01355, 1993.

Maier-Reimer, E., Kriest, I., Segschneider, J., and Wetzel, P.: The Hamburg oceanic carbon cycle circulation model HAMOCC5.1 Technical Description Release 1.1, Tech. Rep., Reports on Earth System Science, Max Planck Institute for Meteorology, Hamburg, 2005.

Makkonen, R., Asmi, A., Korhonen, H., Kokkola, H., Järvenoja, S., Räisänen, P., Lehtinen, K. E. J., Laaksonen, A., Kerminen, V.M., Järvinen, H., Lohmann, U., Bennartz, R., Feichter, J., and Kulmala, M.: Sensitivity of aerosol concentrations and cloud properties to nucleation and secondary organic distribution in ECHAM5-HAM global circulation model, Atmos. Chem. Phys., 9, 1747-1766, doi:10.5194/acp-9-1747-2009, 2009.

Makkonen, R., Asmi, A., Kerminen, V.-M., Boy, M., Arneth, A., Guenther, A., and Kulmala, M.: BVOC-aerosol-climate interactions in the global aerosol-climate model ECHAM5.5-HAM2, Atmos. Chem. Phys., 12, 10077-10096, doi:10.5194/acp-1210077-2012, 2012a.

Makkonen, R., Asmi, A., Kerminen, V.-M., Boy, M., Arneth, A., Hari, P., and Kulmala, M.: Air pollution control and decreasing new particle formation lead to strong climate warming, Atmos. Chem. Phys., 12, 1515-1524, doi:10.5194/acp-12-15152012, 2012b.

Mann, G. W., Carslaw, K. S., Spracklen, D. V., Ridley, D. A., Manktelow, P. T., Chipperfield, M. P., Pickering, S. J., and Johnson, C. E.: Description and evaluation of GLOMAP-mode: a modal global aerosol microphysics model for the UKCA composition-climate model, Geosci. Model Dev., 3, 519-551, doi:10.5194/gmd-3-519-2010, 2010. 
Marinoni, A., Cristofanelli, P., Calzolari, F., Roccato, F., Bonafé, U., and Bonasoni, P.: Continous measurements of aerosol physical parameters at the Mt. Cimone GAW station (2165 m asl, Italy), Sci. Total Environ., 391, 231-251, 2008.

Merikanto, J., Spracklen, D. V., Mann, G. W., Pickering, S. J., and Carslaw, K. S.: Impact of nucleation on global CCN, Atmos. Chem. Phys., 9, 8601-8616, doi:10.5194/acp-9-8601-2009, 2009.

Metzger, A., Verheggen, B., Dommen, J., Duplissy, J., Prevot, A. S. H., Weingartner, E., Riipinen, I., Kulmala, M., Spracklen, D. V., Carslaw, K. S., and Baltensperger, U.: Evidence for the role of organics in aerosol particle formation under atmospheric conditions, P. Natl. Acad. Sci. USA, 107, 6646-6651, doi:10.1073/pnas.0911330107, 2010.

Mihalopoulos, N., Stephanou, E., Kanakidou, M., Pilitsidis, S., and Bousquet, P.: Tropospheric aerosol ionic composition in the Eastern Mediterranean region, Tellus B, 49, 314-326, 1997.

Myhre, G., Samset, B. H., Schulz, M., Balkanski, Y., Bauer, S., Berntsen, T. K., Bian, H., Bellouin, N., Chin, M., Diehl, T., Easter, R. C., Feichter, J., Ghan, S. J., Hauglustaine, D., Iversen, T., Kinne, S., Kirkevåg, A., Lamarque, J.-F., Lin, G., Liu, X., Lund, M. T., Luo, G., Ma, X., van Noije, T., Penner, J. E., Rasch, P. J., Ruiz, A., Seland, Ø., Skeie, R. B., Stier, P., Takemura, T., Tsigaridis, K., Wang, P., Wang, Z., Xu, L., Yu, H., Yu, F., Yoon, J.-H., Zhang, K., Zhang, H., and Zhou, C.: Radiative forcing of the direct aerosol effect from AeroCom Phase II simulations, Atmos. Chem. Phys., 13, 1853-1877, doi:10.5194/acp-13-18532013, 2013.

Nojarov, P., Ivanov, P., Kalapov, I., Penev, I., and Drenska, M.: Connection between ozone concentration and atmosphere circulation at peak Moussala, Theor. Appl. Climatol., 98, 201-208, doi:10.1007/s00704-009-0173-2, 2009.

O'Dowd, C. and Hoffmann, T.: Coastal new particle formation: A review of the current state-of-the-art, Environ. Chem., 2, 245255, doi:10.1071/EN05077, 2005.

O'Dowd, C. D., Hill, M. K., Smith, M. H., Geever, M., and Jennings, S. G.: New particle formation: Nucleation rates \& spatial scales in the coastal environment, J. Aerosol Sci., 29, S183S184, 1998.

Oleson, K., Lawrence, D. M., Bonan, G. B., Flanner, M., Kluzek, E., Lawrence, P., Levis, S., Swenson, S., Thornton, P., Dai, A., Decker, M., Dickinson, R., Feddema, J., Heald, C., Hoffman, F., Lamarque, J., Mahowald, N., Niu, G., Qian, T., Randerson, J., Running, S., Sakaguchi, K., Slater, A., Stockli, R., Wang, A., Yang, Z., Zeng, X., and Zeng., X.: Technical description of version 4.0 of the Community Land Model (CLM), NCAR Technical Note, NCAR/TN-478+STR, 2010.

Otterå, O. H., Bentsen, M., Bethke, I., and Kvamstø, N. G.: Simulated pre-industrial climate in Bergen Climate Model (version 2): model description and large-scale circulation features, Geosci. Model Dev., 2, 197-212, doi:10.5194/gmd-2-197-2009, 2009.

Paasonen, P., Nieminen, T., Asmi, E., Manninen, H. E., Petäjä, T., Plass-Dülmer, C., Flentje, H., Birmili, W., Wiedensohler, A., Hõrrak, U., Metzger, A., Hamed, A., Laaksonen, A., Facchini, M. C., Kerminen, V.-M., and Kulmala, M.: On the roles of sulphuric acid and low-volatility organic vapours in the initial steps of atmospheric new particle formation, Atmos. Chem. Phys., 10, 11223-11242, doi:10.5194/acp-10-11223-2010, 2010.
Pandolfi, M., Cusack, M., Alastuey, A., and Querol, X.: Variability of aerosol optical properties in the Western Mediterranean Basin, Atmos. Chem. Phys., 11, 8189-8203, doi:10.5194/acp-11-81892011, 2011.

Pierce, J. R. and Adams, P. J.: Efficiency of cloud condensation nuclei formation from ultrafine particles, Atmos. Chem. Phys., 7, 1367-1379, doi:10.5194/acp-7-1367-2007, 2007.

Pierce, J. R. and Adams, P. J.: Uncertainty in global CCN concentrations from uncertain aerosol nucleation and primary emission rates, Atmos. Chem. Phys., 9, 1339-1356, doi:10.5194/acp-91339-2009, 2009.

Reddington, C. L., Carslaw, K. S., Spracklen, D. V., Frontoso, M. G., Collins, L., Merikanto, J., Minikin, A., Hamburger, T., Coe, H., Kulmala, M., Aalto, P., Flentje, H., Plass-Dülmer, C., Birmili, W., Wiedensohler, A., Wehner, B., Tuch, T., Sonntag, A., O’Dowd, C. D., Jennings, S. G., Dupuy, R., Baltensperger, U., Weingartner, E., Hansson, H.-C., Tunved, P., Laj, P., Sellegri, K., Boulon, J., Putaud, J.-P., Gruening, C., Swietlicki, E., Roldin, P., Henzing, J. S., Moerman, M., Mihalopoulos, N., Kouvarakis, G., Ždímal, V., Zíkovà, N., Marinoni, A., Bonasoni, P., and Duchi, R.: Primary versus secondary contributions to particle number concentrations in the European boundary layer, Atmos. Chem. Phys., 11, 12007-12036, doi:10.5194/acp-11-12007-2011, 2011

Reddington, C. L., McMeeking, G., Mann, G. W., Coe, H., Frontoso, M. G., Liu, D., Flynn, M., Spracklen, D. V., and Carslaw, K. S.: The mass and number size distributions of black carbon aerosol over Europe, Atmos. Chem. Phys., 13, 4917-4939, doi:10.5194/acp-13-4917-2013, 2013.

Riipinen, I., Pierce, J. R., Yli-Juuti, T., Nieminen, T., Häkkinen, S., Ehn, M., Junninen, H., Lehtipalo, K., Petäjä, T., Slowik, J., Chang, R., Shantz, N. C., Abbatt, J., Leaitch, W. R., Kerminen, V.-M., Worsnop, D. R., Pandis, S. N., Donahue, N. M., and Kulmala, M.: Organic condensation: a vital link connecting aerosol formation to cloud condensation nuclei (CCN) concentrations, Atmos. Chem. Phys., 11, 3865-3878, doi:10.5194/acp-11-38652011, 2011.

Rissler, J., Vestin, A., Swietlicki, E., Fisch, G., Zhou, J., Artaxo, P., and Andreae, M. O.: Size distribution and hygroscopic properties of aerosol particles from dry-season biomass burning in Amazonia, Atmos. Chem. Phys., 6, 471-491, doi:10.5194/acp6-471-2006, 2006.

Rodríguez, S., González, Y., Cuevas, E., Ramos, R., Romero, P. M., Abreu-Afonso, J., and Redondas, A.: Atmospheric nanoparticle observations in the low free troposphere during upward orographic flows at Izaña Mountain Observatory, Atmos. Chem. Phys., 9, 6319-6335, doi:10.5194/acp-9-6319-2009, 2009.

Russchenberg, H., Bosveld, F., Swart, D., Ten Brink, H., De Leeuw, G., Uijlenhoet, R., Arbesser-Rastburg, B., Van Der Marel, H., Ligthart, L., Boers, R., and Apituley, A.: Groundbased atmospheric remote sensing in the Netherlands: European outlook, IEICE Trans. Commun., E88-B, 2252-2257, doi:10.1093/ietcom/e88-b.6.2252, 2005.

Schmeissner, T., Krejci, R., Ström, J., Birmili, W., Wiedensohler, A., Hochschild, G., Gross, J., Hoffmann, P., and Calderon, S.: Analysis of number size distributions of tropical free tropospheric aerosol particles observed at Pico Espejo (4765 m a.s.1.), Venezuela, Atmos. Chem. Phys., 11, 3319-3332, doi:10.5194/acp-11-3319-2011, 2011. 
Shaw, S., Gantt, B., and Meskhidze, N.: Production and Emissions of Marine Isoprene and Monoterpenes: A Review, Advances in Meteorology, 2010, Article ID 408696, doi:10.1155/2010/408696, 2010.

Sihto, S.-L., Kulmala, M., Kerminen, V.-M., Dal Maso, M., Petäjä, T., Riipinen, I., Korhonen, H., Arnold, F., Janson, R., Boy, M., Laaksonen, A., and Lehtinen, K. E. J.: Atmospheric sulphuric acid and aerosol formation: implications from atmospheric measurements for nucleation and early growth mechanisms, Atmos. Chem. Phys., 6, 4079-4091, doi:10.5194/acp-6-4079-2006, 2006.

Spracklen, D. V., Pringle, K. J., Carslaw, K. S., Chipperfield, M. P., and Mann, G. W.: A global off-line model of sizeresolved aerosol microphysics: I. Model development and prediction of aerosol properties, Atmos. Chem. Phys., 5, 2227 2252, doi:10.5194/acp-5-2227-2005, 2005

Spracklen, D. V., Carslaw, K. S., Kulmala, M., Kerminen, V.-M., Mann, G. W., and Sihto, S.-L.: The contribution of boundary layer nucleation events to total particle concentrations on regional and global scales, Atmos. Chem. Phys., 6, 5631-5648, doi:10.5194/acp-6-5631-2006, 2006.

Spracklen, D. V., Carslaw, K. S., Merikanto, J., Mann, G. W., Reddington, C. L., Pickering, S., Ogren, J. A., Andrews, E., Baltensperger, U., Weingartner, E., Boy, M., Kulmala, M., Laakso, L., Lihavainen, H., Kivekäs, N., Komppula, M., Mihalopoulos, N., Kouvarakis, G., Jennings, S. G., O’Dowd, C., Birmili, W., Wiedensohler, A., Weller, R., Gras, J., Laj, P., Sellegri, K., Bonn, B., Krejci, R., Laaksonen, A., Hamed, A., Minikin, A., Harrison, R. M., Talbot, R., and Sun, J.: Explaining global surface aerosol number concentrations in terms of primary emissions and particle formation, Atmos. Chem. Phys., 10, 4775-4793, doi:10.5194/acp-10-4775-2010, 2010.

Spracklen, D. V., Jimenez, J. L., Carslaw, K. S., Worsnop, D. R., Evans, M. J., Mann, G. W., Zhang, Q., Canagaratna, M. R., Allan, J., Coe, H., McFiggans, G., Rap, A., and Forster, P.: Aerosol mass spectrometer constraint on the global secondary organic aerosol budget, Atmos. Chem. Phys., 11, 12109-12136, doi:10.5194/acp-11-12109-2011, 2011.

Stier, P., Feichter, J., Kinne, S., Kloster, S., Vignati, E., Wilson, J., Ganzeveld, L., Tegen, I., Werner, M., Balkanski, Y., Schulz, M., Boucher, O., Minikin, A., and Petzold, A.: The aerosol-climate model ECHAM5-HAM, Atmos. Chem. Phys., 5, 1125-1156, doi:10.5194/acp-5-1125-2005, 2005.

Ström, J., Umegård, J., Tørseth, K., Tunved, P., Hansson, H.C., Holmén, K., Wismann, V., Herber, A., and König-Langlo, G.: One year of particle size distribution and aerosol chemical composition measurements at the Zeppelin Station, Svalbard, March 2000-March 2001, Phys. Chem. Earth, 28, 1181-1190, doi:10.1016/j.pce.2003.08.058, 2003.

Struthers, H., Ekman, A. M. L., Glantz, P., Iversen, T., Kirkevåg, A., Mårtensson, E. M., Seland, Ø., and Nilsson, E. D.: The effect of sea ice loss on sea salt aerosol concentrations and the radiative balance in the Arctic, Atmos. Chem. Phys., 11, 3459-3477, doi:10.5194/acp-11-3459-2011, 2011.

Tunved, P., Ström, J., and Hansson, H.-C.: An investigation of processes controlling the evolution of the boundary layer aerosol size distribution properties at the Swedish background station Aspvreten, Atmos. Chem. Phys., 4, 2581-2592, doi:10.5194/acp-4-2581-2004, 2004.
Tunved, P., Ström, J., and Krejci, R.: Arctic aerosol life cycle: linking aerosol size distributions observed between 2000 and 2010 with air mass transport and precipitation at Zeppelin station, Ny-Ålesund, Svalbard, Atmos. Chem. Phys., 13, 3643-3660, doi:10.5194/acp-13-3643-2013, 2013.

Ulevicius, V., Byčenkienè, S., Remeikis, V., Garbaras, A., Kecorius, S., Andriejauskienė, J., Jasinevičienė, D., and Mocnik, G.: Characterization of pollution events in the East Baltic region affected by regional biomass fire emissions, Atmos. Res., 98, 190-200, doi:10.1016/j.atmosres.2010.03.021, 2010.

Vehkamäki, H., Kulmala, M., Napari, I., Lehtinen, K. E. J., Timmreck, C., Noppel, M., and Laaksonen, A.: An improved parameterization for sulfuric acid/water nucleation rates for tropospheric and stratospheric conditions, J. Geophys. Res., 107, 4622-4631, 2002.

Veltkamp, P., Hansen, K., Barkley, R., and Sievers, R.: Principal component analysis of summertime organic aerosols at Niwot Ridge, Colorado, J. Geophys. Res.-Atmos., 101, 19495-19504, 1996.

Venzac, H., Sellegri, K., Laj, P., Villani, P., Bonasoni, P., Marinoni, A., Cristofanelli, P., Calzolari, F., Fuzzi, S., Decesari, S., Facchini, M.-C., Vuillermoz, E., and Verza, G.: High frequency new particle formation in the Himalayas, P. Natl. Acad. Sci. USA, 105, 15666-15671, doi:10.1073/pnas.0801355105, 2008.

Venzac, H., Sellegri, K., Villani, P., Picard, D., and Laj, P.: Seasonal variation of aerosol size distributions in the free troposphere and residual layer at the puy de Dôme station, France, Atmos. Chem. Phys., 9, 1465-1478, doi:10.5194/acp-9-1465-2009, 2009.

Vertenstein, M., Craig, T., Middleton, A., Feddema, D., and Fischer, C.: CCSM4.0 User's Guide, available at: http://www.cesm. ucar.edu/models/ccsm4.0/ccsm_doc/book1.html (last access: 15 January 2014), 2010.

Von Salzen, K., Leighton, H., Ariya, P., Barrie, L., Gong, S., Blanchet, J.-P., Spacek, L., Lohmann, U., and Kleinman, L.: Sensitivity of sulphate aerosol size distributions and $\mathrm{CCN}$ concentrations over North America to $\mathrm{SO}_{\mathrm{x}}$ emissions and $\mathrm{H}_{2} \mathrm{O}_{2}$ concentrations, J. Geophys. Res.-Atmos., 105, 9741-9765, 2000.

Wai, K., Lin, N.-H., Wang, S.-H., and Dokiya, Y.: Rainwater chemistry at a high-altitude station, Mt. Lulin, Taiwan: Comparison with a background station, Mt. Fuji, J. Geophys. Res.-Atmos., 113, D06305, doi:10.1029/2006JD008248, 2008.

Weingartner, E., Nyecki, S., and Baltensberger, U.: Seasonal and diurnal variation of aerosol size distributions $(10<D<750 \mathrm{~nm})$ at a high-alpine site (Jungfraujoch $3580 \mathrm{~m}$ asl), J. Geophys. Res., 104, 26809-26820, 1999.

Weller, R., Minikin, A., Wagenbach, D., and Dreiling, V.: Characterization of the inter-annual, seasonal, and diurnal variations of condensation particle concentrations at Neumayer, Antarctica, Atmos. Chem. Phys., 11, 13243-13257, doi:10.5194/acp11-13243-2011, 2011.

Yli-Juuti, T., Nieminen, T., Hirsikko, A., Aalto, P. P., Asmi, E., Hõrrak, U., Manninen, H. E., Patokoski, J., Dal Maso, M., Petäjä, T., Rinne, J., Kulmala, M., and Riipinen, I.: Growth rates of nucleation mode particles in Hyytiälä during 20032009: variation with particle size, season, data analysis method and ambient conditions, Atmos. Chem. Phys., 11, 12865-12886, doi:10.5194/acp-11-12865-2011, 2011.

Yu, F., Wang, Z., Luo, G., and Turco, R.: Ion-mediated nucleation as an important global source of tropospheric aerosols, At- 
mos. Chem. Phys., 8, 2537-2554, doi:10.5194/acp-8-2537-2008, 2008.

Zhang, K., O’Donnell, D., Kazil, J., Stier, P., Kinne, S., Lohmann, U., Ferrachat, S., Croft, B., Quaas, J., Wan, H., Rast, S., and Feichter, J.: The global aerosol-climate model ECHAM-HAM, version 2: sensitivity to improvements in process representations, Atmos. Chem. Phys., 12, 8911-8949, doi:10.5194/acp-12-89112012, 2012.
Ziemba, L., Griffin, R., and Talbot, R.: Observations of elevated particle number concentration events at a rural site in New England, J. Geophys. Res.-Atmos., 111, D23S34, doi:10.1029/2006JD007607, 2006.

Zíková, N. and Ždímal, V.: Long-term measurement of aerosol number size distributions at rural background station Košetice, Aerosol Air Qual. Res., 13, 1464-1474, doi:10.4209/aaqr.2013.02.0056, 2013. 